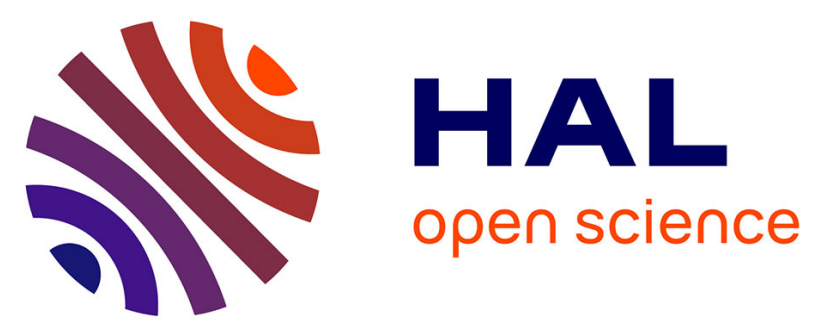

\title{
Chemo-enzymatic synthesis of a series of 2,4-syn-functionalized (S)-glutamate analogues: new insight into the structure-activity relation of ionotropic glutamate receptor subtypes 5,6 , and 7 .
}

Emmanuelle Sagot, Darryl S. Pickering, Xiasui Pu, Michelle Umberti, Tine B. Stensbol, Brigitte Nielsen, Marion Chapelet, Jean Bolte, Thierry Gefflaut, Lennart Bunch

\section{- To cite this version:}

Emmanuelle Sagot, Darryl S. Pickering, Xiasui Pu, Michelle Umberti, Tine B. Stensbol, et al.. Chemoenzymatic synthesis of a series of 2,4-syn-functionalized (S)-glutamate analogues: new insight into the structure-activity relation of ionotropic glutamate receptor subtypes 5, 6, and 7.. Journal of Medicinal Chemistry, 2008, 51, pp.4093-4103. hal-00323861

\section{HAL Id: hal-00323861 https://hal.science/hal-00323861}

Submitted on 23 Sep 2008

HAL is a multi-disciplinary open access archive for the deposit and dissemination of scientific research documents, whether they are published or not. The documents may come from teaching and research institutions in France or abroad, or from public or private research centers.
L'archive ouverte pluridisciplinaire HAL, est destinée au dépôt et à la diffusion de documents scientifiques de niveau recherche, publiés ou non, émanant des établissements d'enseignement et de recherche français ou étrangers, des laboratoires publics ou privés. 


\title{
Chemo-Enzymatic Synthesis of a Series of 2,4-Syn-Functionalized (S)-Glutamate Analogues: New Insight into the Structure-Activity Relation of Ionotropic Glutamate Receptor Subtypes 5, 6, and 7
}

\author{
Emanuelle Sagot, ${ }^{\ddagger}$ Darryl S. Pickering, ${ }^{\S}$ Xiaosui Pu, ${ }^{\prime \prime}$ Michelle Umberti, ${ }^{\dagger}$ Tine B. Stensbøl, ${ }^{\perp}$ Birgitte Nielsen, ${ }^{\dagger}$ Marion Chapelet, ${ }^{\ddagger}$ \\ Jean Bolte, ${ }^{\ddagger}$ Thierry Gefflaut, ${ }^{*} \neq$ and Lennart Bunch*** \\ Department of Medicinal Chemistry, The Faculty of Pharmaceutical Sciences, University of Copenhagen, Universitetsparken 2, DK-2100 \\ Copenhagen, Denmark, Département de Chimie, Université Blaise Pascal, 63177 Aubière Cedex, France, Department of Pharmacology and \\ Pharmacotherapy, The Faculty of Pharmaceutical Sciences, University of Copenhagen, Universitetsparken 2, DK-2100 Copenhagen, Denmark, \\ Biological Research, H. Lundbeck A/S, 215 College Road, Paramus, New Jersey 07652, Department of Neurobiology, H. Lundbeck A/S, \\ Ottiliavej 9, DK-2500 Valby, Denmark
}

(S)-Glutamic acid (Glu) is the major excitatory neurotransmitter in the central nervous system (CNS) activating the plethora of ionotropic Glu receptors (iGluRs) and metabotropic Glu receptors (mGluRs). In this paper, we present a chemo-enzymatic strategy for the enantioselective synthesis of five new Glu analogues $\mathbf{2} \mathbf{a}-\mathbf{f}$ (2d is exempt) holding a functionalized substituent in the 4-position. Nine Glu analogues $\mathbf{2} \mathbf{a}-\mathbf{j}$ are characterized pharmacologically at native 2-amino-3-(3-hydroxy-5-methyl-4-isoxazolyl)propionic acid (AMPA), kainic acid (KA), and $N$-methyl-D-aspartic acid (NMDA) receptors in rat synaptosomes as well as in binding assays at cloned rat iGluR5-7 subtypes. A detailed in silico study address as to why $\mathbf{2 h}$ is a high-affinity ligand at iGluR5 $-7\left(K_{\mathrm{i}}=3.81,123,57.3 \mathrm{nM}\right.$, respectively), while $2 \mathrm{e}$ is only a high affinity ligand at iGluR5 $\left(K_{\mathrm{i}}=42.8 \mathrm{nM}\right)$. Furthermore, a small series of commercially available iGluR ligands are characterized in iGluR5 -7 binding.

\section{Introduction}

(S)-Glutamic acid (Glu) is the major excitatory neurotransmitter in the central nervous system (CNS) activating the plethora of ionotropic Glu receptors (iGluRs) ${ }^{a}$ and metabotropic Glu receptors (mGluRs). ${ }^{1,2}$ While the iGluRs are ion channels and thus mediate a fast excitatory response $\left(\mathrm{Na}^{+}, \mathrm{K}^{+}, \mathrm{Ca}^{2+}\right.$ flux), the mGluRs are classified as G-protein coupled receptors and produce a slower signal transduction through second messenger systems. Termination of the excitatory signal is controlled by uptake of Glu from the synaptic cleft by the excitatory amino acid transporters (EAATs). ${ }^{3}$ On the basis of pharmacological studies, the iGluRs are further divided into: 2-amino-3-(3-hydroxy-5-methyl-4-isoxazolyl)propionic acid (AMPA) receptors (homo- or heteromeric receptors comprising the subunits iGluR1-4), kainic acid (KA) receptors (homo- or heteromeric receptors comprising the subunits iGluR5 -7 and $\mathrm{KA} 1,2),{ }^{4}$ and the $N$-methyl-D-aspartic acid (NMDA) receptors (heteromeric receptors comprising the subunits NR1, 2A-D, 3AC). The mGluRs are divided into eight homodimeric subtypes,

* Author to whom correspondence should be addressed. For L.B.: phone, +45 35336244; fax, +45 35336040; E-mail, lebu@farma.ku.dk. For T.G. (for correspondence regarding the synthetic work): phone, +33473407866 ; fax, +33 473407717; E-mail, thierry.gefflaut@univ-bpclermont.fr.

Département de Chimie, Université Blaise Pascal.

${ }^{s}$ Department of Pharmacology and Pharmacotherapy, The Faculty of Pharmaceutical Sciences, University of Copenhagen.

"Biological Research, H. Lundbeck A/S.

${ }^{\perp}$ Department of Neurobiology, H. Lundbeck A/S.

${ }^{\dagger}$ Department of Medicinal Chemistry, The Faculty of Pharmaceutical Sciences, University of Copenhagen.

${ }^{a}$ Abbreviations: iGluR, ionotropic Glu receptors; mGluR, metabotropic Glu receptors; EAAT, excitatory amino acid transporter; KG, $\alpha$-ketoglutarates; AAT, aspartate aminotransferase; DHK, dihydrokainic acid; TBOA, threo-benzyloxyaspartate; AMPA, 2-amino-3-(3-hydroxy-5-methyl-4-isoxazolyl)propionic acid; KA, kainic acid; NMDA, $N$-methyl-D-aspartic acid; FMP, FLIPR membrane potential; DOMO, domoric acid; QUIS, quisqualic acid.
mGluR1-8, which are grouped with respect to the second messenger system involved with receptor signaling, pharmacology, and molecular biology (group I: mGluR1,5; group II: mGluR2,3; group III: mGluR4,6-8). ${ }^{5}$

To study a specific iGluR subtype, when functioning in its intrinsic biological environment, the employment of iGluR subtype selective ligands (agonists, partial agonists, and antagonists) is a frequently applied strategy. In this paper, we present the synthetic strategy which allowed the preparation of Glu analogues $\mathbf{2 a}-\mathbf{f}$ ( $\mathbf{2 d}$ is exempt), and the pharmacological evaluation of the nine 2,4-syn-4-substituted Glu analogues $\mathbf{2 a - j}$ at iGluRs. New insight into the structure-activity relation for KA receptor subtypes iGluR5-7 is presented.

\section{Chemistry}

Glu analogues $\mathbf{2} \mathbf{a}-\mathbf{j}$ were all prepared following a chemoenzymatic route involving a stereoselective transamination reaction as the key step (Scheme 1). Aspartate aminotransferase (AAT) from Escherichia coli was shown to be a very effective catalyst for the conversion of a variety of substituted $\alpha$-ketoglutarates (KG) into L-Glu analogues. A very high stereoselectivity was observed in favor of the L-2,4-syn Glu analogues obtained through the kinetic resolution of racemic KGs. ${ }^{6}$

Synthesis of 2-Oxoglutaric Acids. Two synthetic approaches were developed for the preparation of the oxoglutarates $1 \mathbf{1}-\mathbf{j}$. Substrates $\mathbf{1} \mathbf{g}-\mathbf{j}$ bearing the amide functionality were prepared via a short three-step procedure from the readily available dimethyl 4-oxocyclohexane-1,3-dicarboxylate. ${ }^{7}$ However, this method was not feasible for introduction of the functionalities present in $\mathbf{1 a}-\mathbf{f}$.

As shown in Scheme 2, the syntheses of $1 \mathbf{a}-\mathbf{c}$ were performed by following a recently described procedure: ${ }^{8}$ the glutarate carbon skeleton was obtained by a Michael reaction between methyl acetoacetate and an $\alpha$-substituted acrylate, 
Scheme 1. AAT Catalyzed Synthesis of 4-Substituted Glu Analogues

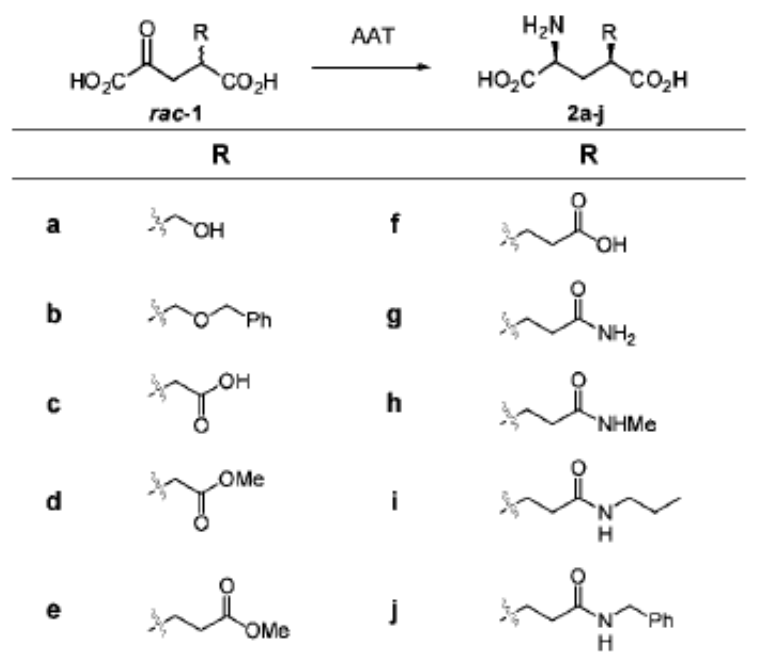

Scheme 2. Synthesis of 4-Substituted KG 1a-c

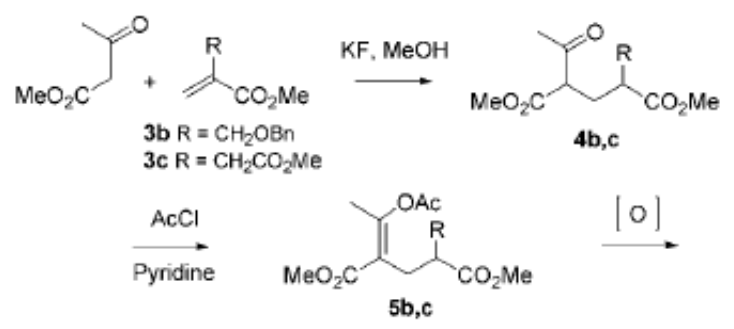

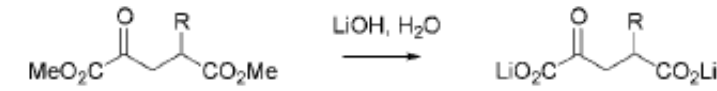

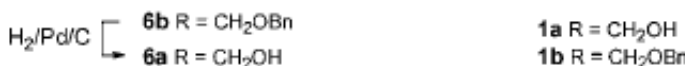

$$
\begin{aligned}
& 6 \mathrm{CR}=\mathrm{CH}_{2} \mathrm{CO}_{2} \mathrm{Me} \quad \text { 1c R }=\mathrm{CH}_{2} \mathrm{CO}_{2} \mathrm{~L}
\end{aligned}
$$

whereas ozonolysis of an enol acetate intermediate afforded the $\alpha$-keto ester moiety. This strategy, already used for the synthesis of 3 -alkyl KGs, ${ }^{8}$ appeared very general and compatible with the functionalities of $\mathbf{1 a - c}$.

2-(Benzyloxymethyl)acrylate (3b) was prepared from methyl (bromomethyl)acrylate ${ }^{9}$ by reaction with benzyl alcohol in the presence of base. Among the several bases tested, 1,4diazabicyclo[2.2.2] octane (DABCO) gave the best results for the preparation of $\mathbf{3 b}$, which was isolated in $80 \%$ yield. The Michael condensations of $\mathbf{3 b}, \mathbf{c}$ with methyl acetoacetate were done in mild conditions using $\mathrm{KF}$ as the base in $\mathrm{MeOH}$. The Michael products $\mathbf{4 b}$ and $\mathbf{4 c}$ were both isolated as 1:1 mixtures of diastereomers and in $95 \%$ and $78 \%$ yields, respectively. These $\beta$-keto esters were then treated with acetyl chloride and pyridine to form the enol acetates $\mathbf{5 b}$ and $\mathbf{5} \mathbf{c}$ isolated after flash chromatography in $64 \%$ and $86 \%$ yields, respectively. Finally, these intermediates were oxidized by ozone to form the oxoglutarates $\mathbf{6 b}$ and $\mathbf{6 c}$. A yield of $72 \%$ was obtained for $\mathbf{6 c}$. Unfortunately, using the same ozonolysis procedure, the oxoglutarate $\mathbf{6 b}$ was isolated with a low yield of $17 \%$. This result was mainly due to an unexpected oxidation of the benzyl ether group to a benzoate isolated as the major byproduct in $45 \%$ yield. The oxidative cleavage of $\mathbf{5 b}$ was tried using $\mathrm{NaIO}_{4}$ and catalytic $\mathrm{RuO}_{2}$ in biphasic conditions using a $\mathrm{CHCl}_{3} / \mathrm{CH}_{3} \mathrm{CN} /$ $\mathrm{H}_{2} \mathrm{O}$ mixture. However, hydrolysis of the enol acetate $\mathbf{5 b}$ was observed in these conditions and the yield of $\mathbf{6} \mathbf{b}$ could only be
Scheme 3. Synthesis of 4-Hydroxymethyl KG 1a<smiles>CC(=O)OC(C)(C)C1CC(C(C)C)CO1</smiles>

Scheme 4. Synthesis of 1d and 1e

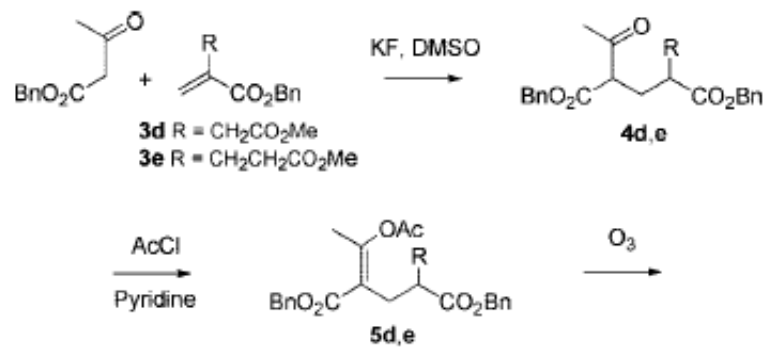

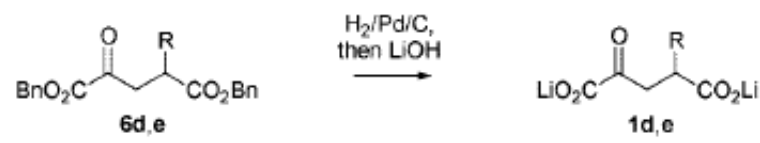

Scheme 5. Synthesis of Acrylates 3d and 3e
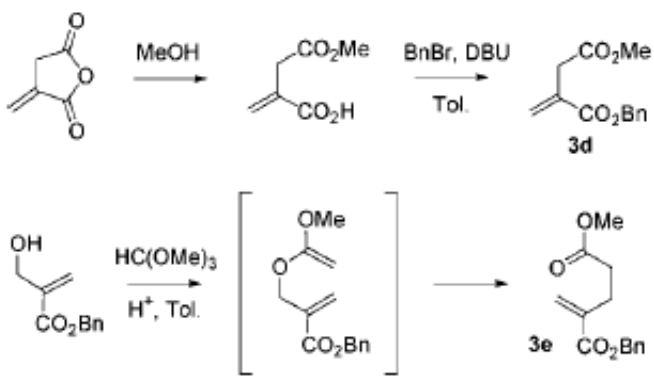

increased to $43 \%$. The benzyl group of $\mathbf{6 b}$ was cleaved by hydrogenolysis to furnish $\mathbf{6 a}$ in quantitative yield. Finally, the lithium salts $1 \mathrm{a}-\mathrm{c}$ were prepared quantitatively from $\mathbf{6 a}-\mathbf{c}$ by basic hydrolysis using a stoichiometric amount of $\mathrm{LiOH}$. Interestingly, NMR analyses indicated that both compounds 6 a and 1a exist in solution as a 1:1 mixture of hemiketal isomers, coming from the addition of the hydroxyl group on the carbonyle at position 2 (Scheme 3).

The synthesis of ketoglutarates 1d and 1e bearing an ester functionality was performed following a slightly different procedure (Scheme 4): the Michael condensation of 3d,e with benzylacetoacetate was done in DMSO in order to avoid the transesterification reaction occurring when $\mathrm{MeOH}$ was used as the solvent. The ketoesters $\mathbf{6} \mathbf{d}$ and $\mathbf{6 e}$ were thus obtained from 3d and $3 \mathrm{e}$ in $40 \%$ overall yield. Finally, the methyl ester functionality of $1 d$ and 1 e could be preserved through the selective hydrogenolysis of the benzyl esters of $\mathbf{6 c}$ and $\mathbf{6 d}$ in the presence of $\mathrm{Pd} / \mathrm{C}$.

As shown in Scheme 5, the unsymmetrical diester 3d was obtained from itaconic anhydride: regioselective addition of $\mathrm{MeOH}$ on the nonconjugated carbonyl of the anhydride allowed the formation of itaconic acid monoester at position 1. Consecutiveesterification withbenzylbromideand 1,8-diazabicyclo[5.4.0]undec7-ene (DBU) afforded 1-methyl-4-benzyl itaconate 3d isolated in $95 \%$ overall yield. The methyl ester formation was highly 
Table 1. Kinetic Parameters of AAT Catalyzed Transaminations with KG Analogues $1 \mathbf{a}^{-} \mathbf{e}^{a}$

\begin{tabular}{|c|c|c|c|}
\hline Substrate & $\mathbf{R}$ & $K_{m}(\mathbf{m} \mathbf{M})$ & $\mathbf{k}_{\text {cat }}$ rel.(\%) \\
\hline $\mathrm{KG}$ & - & $0.23 \pm 0.05$ & $100 \pm 3^{b}$ \\
\hline 1a & $\mathrm{OH}$ & $4.7 \pm 0.8$ & $1.6 \pm 0.3$ \\
\hline $1 b$ & & $0.09 \pm 0.04$ & $11.0 \pm 0.8$ \\
\hline 1c & & $30.1 \pm 106$ & $1.1 \pm 0.06$ \\
\hline 1d & & $1.8 \pm 0.4$ & $41.0 \pm 2.0$ \\
\hline $1 \mathrm{e}$ & & $0.61 \pm 0.03$ & $33.6 \pm 0.6$ \\
\hline
\end{tabular}

${ }^{a}$ Values and standard errors were calculated from the Hanes-Woolf plot according to the least-squares method and Gauss's error propagation law. ${ }^{b}$ The absolute $k_{\text {cat }}$ value measured in our experimental conditions was $39.6 \pm 1.2 \mathrm{~s}^{-1}$

regioselective, giving a 97:3 mixture of 3d and 1-benzyl-4methyl itaconate. Acrylate 3 e was prepared in $73 \%$ yield from benzyl $\alpha$-(hydroxymethyl)acrylate ${ }^{\text {fo }}$ via the Claisen-Johnson rearrangement of the ketene ketal formed in the presence of trimethyl orthoacetate. ${ }^{11}$

Transamination Reactions. The substituted KGs 1a-e were evaluated as substrate for $E$. coli AAT on the basis of the Michaelis-Menten model: rate measurement of the AAT catalyzed transaminations between aspartate $(40 \mathrm{mM})$ and $\mathbf{1 a}-\mathbf{e}$ in variable concentrations allowed estimation of the kinetic parameters reported in Table 1.

These results offer a new highlight on the substrate specificity of AAT: the parameters measured for 1a and, even more, for 1c clearly indicate that the introduction of a polar group at position 4 of $\mathrm{KG}$ results in a dramatic drop in affinity as well as in $k_{\text {cat }}$ value. The low activity of AAT toward 1a could be the result of the cyclization mentioned above, hiding the carbonyl group of this substrate. The low affinity of AAT toward substrate, which contain polar functional groups, was also noticed with the amide derivatives precursors of $\mathbf{2} \mathbf{g}-\mathbf{j}^{7}$ However, when the alcohol and carboxylic acid functionalities are masked as benzyl ether or methyl ester in compounds $\mathbf{1 b}$, 1d, and 1e, the activity is restored. These results are consistent with the previous finding that the AAT active site accommodates various hydrophobic groups substituting the pro- $R$ hydrogen atom at position 4 of $\mathrm{KG}^{6}$

Preparative scale transaminations were easily carried out in the case of the 3 protected derivatives $\mathbf{1 b}, \mathbf{1 d}$, and $\mathbf{1 e}$ following the procedure described previously: ${ }^{6,8}$ cysteine sulfinic acid (CSA) was used as an irreversible amino donor, and the reaction was stopped near $40 \%$ conversion. Therefore, the kinetic resolution of the racemic substrates $\mathbf{1 b}, \mathbf{d}, \mathbf{e}$ was performed, resulting in the stereoselective formation of L-2,4-syn Glu analogues $\mathbf{2 b , d , e . ~ T h e ~ G l u ~ a n a l o g u e ~} \mathbf{2 b}$ was isolated after selective adsorption on sulfonic dowex $50 \mathrm{resin}\left(\mathrm{H}^{+}\right.$form $)$and elution with aqueous ammonia. It was further purified by ion exchange chromatography on cationic dowex 1 resin $\left(\mathrm{AcO}^{-}\right.$ form): elution with an AcOH gradient afforded $\mathbf{2 b}$ isolated in $43 \%$ yield and with a diastereomeric excess over $98 \%$. Hydrogenation of $\mathbf{2} \mathbf{b}$ in the presence of $\mathrm{Pd} / \mathrm{C}$ gave $\mathbf{2 a}$ in quantitative yield. In this way, the low activity of AAT toward 1a could be bypassed through "substrate tailoring" by the design
Scheme 6. Instant Cyclization of $\mathbf{2 d}$ into Lactam 7<smiles>COC(=O)CC(CC(N)C(=O)O)C(=O)O</smiles><smiles>O=C1CC(C(=O)O)CC(C(=O)O)N1</smiles>
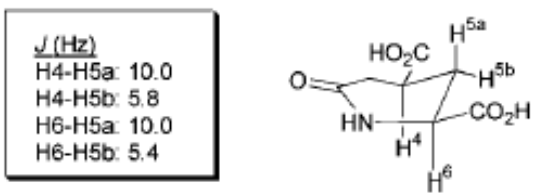

and synthesis of $\mathbf{1 b}$ behaving as a very good substrate of AAT. The same strategy was applied for the tricarboxylic acid $2 \mathrm{c}$ : after the transamination reaction involving the ester 1d, the crude product was refluxed with $6 \mathrm{~N} \mathrm{HCl}$ to hydrolyze the ester group of $\mathbf{2 d}$. The Glu analogue $2 \mathrm{c}$ was then purified by ion exchange chromatography as described for $\mathbf{2 b}$ and isolated in $41 \%$ yield from $\mathrm{rac}$-1d. All attempts to isolate $\mathbf{2 d}$ were unsuccessful due to its rapid base catalyzed cyclization into lactame 7. NMR analysis of the cyclic derivative 7 allowed the confirmation of the pseudoaxial position of $\mathrm{H}^{4}$ and $\mathrm{H}^{6}$, i.e., a 2,4-syn configuration in $\mathbf{2} \mathbf{c}$ and $\mathbf{2} \mathbf{d}$, which is in agreement with the previously observed stereoselectivity of AAT toward 4-substituted Glu analogues (Scheme 6).

The tricarboxylic Glu analogue $\mathbf{2 f}$ was prepared from $\mathbf{2 e}$ following the procedure described above for $2 \mathbf{c}$ : $\mathrm{HCl}$ catalyzed hydrolysis of $\mathbf{2 e}$ before purification by ion exchange chromatography afforded $\mathbf{2 f}$ in $40 \%$ yield. Contrary to $\mathbf{2 d}$, the Glu analogue $2 \mathrm{e}$ bearing the methyl ester functionality could be isolated because the cyclization giving a seven-membered ring lactame was not favored in this case. $2 \mathbf{e}$ was isolated in $39 \%$ yield after purification on the cationic dowex 1 resin. In this case, the first chromatographic step on dowex 50 was omitted in order to avoid the ester hydrolysis during elution with aqueous ammonia.

Pharmacology. The pharmacological properties of the nine 2,4-syn-4-substituted Glu analogues $\mathbf{2} \mathbf{a}-\mathbf{j}$ were first evaluated for binding affinities at native AMPA, KA, and NMDA receptor, ${ }^{12}$ and results are summarized in Table 2 . In $\left[{ }^{3} \mathrm{H}\right] \mathrm{AMPA}$ binding, all nine Glu analogues showed mid-to-high range micromolar affinities $\left(\mathrm{IC}_{50}=25\right.$ to $\left.>100 \mu \mathrm{M}\right)$. The same trend was observed in $\left[{ }^{3} \mathrm{H}\right] \mathrm{KA}$ binding experiments, except for $\mathbf{2 a}$, which was found to exhibit high nanomolar affinity $\left(\mathrm{IC}_{50}=\right.$ $0.24 \mu \mathrm{M})$. Binding affinities for NMDA receptors were determined by means of the radioactive ligand $\left[{ }^{3} \mathrm{H}\right] \mathrm{CGP} 39653$. Again we observed mid-to-high micromolar affinities $\left(K_{\mathrm{i}}=15\right.$ to $>100$ $\mu \mathrm{M})$ for the nine compounds.

We subsequently investigated the binding affinities of $\mathbf{2} \mathbf{a}-\mathbf{j}$ at recombinant homomeric rat iGluR5, iGluR6, and iGluR7 expressed in $5 f 9$ cell membranes (Table 2). Compounds $\mathbf{2 b , c , \mathbf { f }}$ were found to be low affinity ligands (low-high micromolar range) at all three subtypes, iGluR5-7. However, methylester analogue $2 \mathrm{e}$ and amide analogue $\mathbf{2 g}$ displayed high binding affinity for the iGluR5 subtype (42.8 and $7.45 \mathrm{nM}$, respectively), whereas they exhibited low affinity for the two other subtypes, iGluR6,7 (1-10 $\mu \mathrm{M}$ range). Unexpectedly, this subtype affinity profile was discontinued for the methylamide analogue, $\mathbf{2 h}$, which showed high affinity for all three subtypes, iGluR5-7 (3.81, 123, $57.3 \mathrm{nM}$, respectively). Furthermore, upon extending the $N$-alkyl substituent of $\mathbf{2 h}$ to an $N$-n-propyl group, $\mathbf{2} \mathbf{i}$, or a 
Table 2. Binding Affinities at Native iGluRs (Rat Synaptosomes) and at Cloned Rat iGluR5-7 Subtypes ${ }^{a}$

\begin{tabular}{|c|c|c|c|c|c|c|c|}
\hline & $\begin{array}{l}\text { Compound } \\
\text { (R-group) }\end{array}$ & $\begin{array}{l}\left.{ }^{3} \mathrm{H}\right] \mathrm{AMPA} \\
\mathrm{IC}_{50}(\mu \mathrm{M})^{a}\end{array}$ & $\begin{array}{c}{\left[{ }^{3} \mathbf{H}\right] \mathbf{K A}} \\
\mathrm{IC}_{50}(\mu \mathbf{M})^{a}\end{array}$ & $\begin{array}{c}\mathbf{N M D A}^{d} \\
\mathbf{K}_{\mathrm{i}}(\mu \mathbf{M})^{a}\end{array}$ & $\begin{array}{c}\text { Rat } \\
\text { iGluR5 } \\
\mathbf{K}_{\mathbf{i}}(\mathbf{n M})^{a, b}\end{array}$ & $\begin{array}{c}\text { Rat } \\
\text { iGluR6 } \\
\mathbf{K}_{\mathbf{i}}(\mathbf{n M})^{a, b}\end{array}$ & $\begin{array}{c}\text { Rat } \\
\text { iGluR7 } \\
\mathbf{K}_{\mathbf{i}}(\mathbf{n M})^{a, b}\end{array}$ \\
\hline $2 a$ & $\widehat{\gamma 0}$ & $\begin{array}{c}44 \\
{[4.35 \pm 0.01]}\end{array}$ & $\begin{array}{c}0.24 \\
{[6.62 \pm 0.04]}\end{array}$ & $\begin{array}{c}15 \\
{[4.82 \pm 0.01]}\end{array}$ & n.t. & n.t. & n.t. \\
\hline $2 b$ & & $>100$ & $\begin{array}{c}12 \\
{[4.93 \pm 0.01]}\end{array}$ & $\begin{array}{c}26 \\
{[4.59 \pm 0.05]}\end{array}$ & c) & c) & c) \\
\hline $2 c$ & & $>100$ & $\begin{array}{c}39 \\
{[4.41 \pm 0.01]}\end{array}$ & $>100$ & c) & c) & c) \\
\hline $2 e$ & & $\begin{array}{c}31 \\
{[4.51 \pm 0.02]}\end{array}$ & $\begin{array}{c}7.9 \\
{[5.10 \pm 0.01]}\end{array}$ & $>100$ & $\begin{array}{c}42.8 \\
{[7.38 \pm 0.06]}\end{array}$ & $\begin{array}{c}6,670 \\
{[5.21 \pm 0.10]}\end{array}$ & $\begin{array}{c}1,010 \\
{[6.02 \pm 0.11]}\end{array}$ \\
\hline $2 f$ & & $>100$ & $>100$ & $\begin{array}{c}52 \\
{[4.28 \pm 0.05]}\end{array}$ & c) & c) & c) \\
\hline $2 \mathrm{~g}$ & & $\begin{array}{c}25 \\
{[4.60 \pm 0.05]}\end{array}$ & $\begin{array}{c}16 \\
{[4.80 \pm 0.05]}\end{array}$ & $>100$ & $\begin{array}{c}7.45 \\
{[8.18 \pm 0.12]}\end{array}$ & $\begin{array}{c}9,660 \\
{[5.02 \pm 0.02]}\end{array}$ & $\begin{array}{c}2,820 \\
{[5.59 \pm 0.15]}\end{array}$ \\
\hline $2 h$ & & $\begin{array}{c}32 \\
{[4.51 \pm 0.07]}\end{array}$ & $\begin{array}{c}29 \\
{[4.54 \pm 0.03]}\end{array}$ & $>100$ & $\begin{array}{c}3.81 \\
{[8.42 \pm 0.01]}\end{array}$ & $\begin{array}{c}123 \\
{[6.92 \pm 0.04]}\end{array}$ & $\begin{array}{c}57.3 \\
{[7.30 \pm 0.13]}\end{array}$ \\
\hline $2 \mathrm{i}$ & & $\begin{array}{c}74 \\
{[4.13 \pm 0.04]}\end{array}$ & $\begin{array}{c}41 \\
{[4.39 \pm 0.04]}\end{array}$ & $>100$ & $\begin{array}{c}641 \\
{[6.20 \pm 0.04]}\end{array}$ & $\begin{array}{c}10,600 \\
{[4.99 \pm 0.06]}\end{array}$ & $\begin{array}{c}3,460 \\
{[5.49 \pm 0.10]}\end{array}$ \\
\hline $2 \mathrm{j}$ & & $>100$ & $>100$ & $\begin{array}{c}72 \\
{[4.14 \pm 0.04]}\end{array}$ & $\begin{array}{c}138 \\
{[6.86 \pm 0.03]}\end{array}$ & $>100,000$ & $\begin{array}{c}21,400 \\
{[4.67 \pm 0.02]}\end{array}$ \\
\hline
\end{tabular}

\footnotetext{
${ }^{a}$ Data are given as mean [mean $p \mathrm{IC}_{50}$ or mean $\left.p \mathrm{~K}_{\mathrm{i}}(\mathrm{M}) \pm \mathrm{S} . \mathrm{E} . \mathrm{M}.\right]$ of at least three independent experiments. ${ }^{b}$ Hill-values are close to unity for all compounds. ${ }^{\circ}$ The compound displayed weak binding affinity to this iGluR subtype (low-high micro-molar range). ${ }^{d}$ Radio ligand: $\left[{ }^{3} \mathrm{H}\right] \mathrm{CGP} 39653$. n.t. $=$ not tested.
}

benzyl group, $\mathbf{2 j}$, the preference for subtype iGluR5 over iGluR6,7 was observed again. However, with lower affinities for iGluR5 (641 and $138 \mathrm{nM}$, respectively), as compared with 2e,g,h.

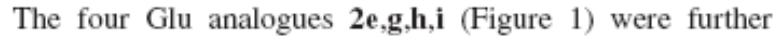
characterized in a functional assay at subtypes mGluR1,5 (group I), mGluR2 (group II), and mGluR4 (group III). None of the analogues displayed agonist, antagonist, nor modulatory activities at these mGluR subtypes $\left(\mathrm{EC}_{50}>100 \mu \mathrm{M}\right)$. Moreover, these four compounds exhibited low affinity $\left(K_{\mathrm{i}}>1000 \mu \mathrm{M}\right)$ for subtypes mGluR2,3 (group II) in binding assays.

\section{Discussion}

The orthosteric binding pocket of the KA receptor subtypes KA1,2 and iGluR5-7 are highly confined compartments. The key amino acid residues involved in the molecular recognition of Glu are highly conserved and can be identified from receptor protein crystallographic studies ${ }^{13,14}$ or receptor subtype homology models built from such data (Table 3 ). In detail (numbering for iGluR5 used, Figure 2), the $\alpha$-carboxylate group of Glu forms hydrogen bonds to the guanidinium side chain of Arg538 and backbone amide-NH of Thr533 and Ser704. The $\alpha$-ammonium group of Glu hydrogen bonds to the $\gamma$-carboxylate group of Glu738 and amide-carbonyl of backbone residue Pro531, whereas the $\gamma$-carbox ylate group of Glu hydrogen bonds to the $\beta-\mathrm{OH}$ and amide-NH of Thr705. Residue Tyr488 does not form specific interactions with Glu but is significant in the

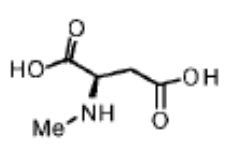

NMDA<smiles>Cc1onc(O)c1C[C@H](N)C(=O)O</smiles>

(S)-AMPA<smiles>C=C(C)[C@H]1CNC(C(=O)O)[C@H]1CC(=O)O</smiles>

KA<smiles>CC(C)[C@H]1CNC(C(=O)O)C1CC(=O)O</smiles>

DHK<smiles>CC(=CC=CC(C)C(=O)O)C1CNC(C(=O)O)C1CC(=O)O</smiles>

DOMO<smiles>N[C@@H](Cn1oc(=O)nc1O)C(=O)O</smiles>

(S)-QUIS
Figure 1. Commercially available standard GluR ligands: NMDA, (S)AMPA, KA, DHK, DOMO, and (S)-QUIS.

sense that it participates strongly in the occluding of the binding pocket (Table 3 ).

In contrast to the above-described structural similarities of the KA receptor binding pockets, the most prominent residues of differentiationare:Thr706(KA1), Thr705(KA2), Ser736(iGluR5), Asn721(iGluR6), and Asn723(iGluR7). The residues are found 


\begin{tabular}{|c|c|c|c|c|c|}
\hline & \multicolumn{3}{|c|}{ conserved ligand-amino acid residue interactions $(\mathrm{CI})^{c}$} & \multirow{2}{*}{$\begin{array}{c}\text { conserved } \\
\text { residues(CR) }\end{array}$} & \multirow{2}{*}{$\begin{array}{c}\text { residues of } \\
\text { differentiation (RD) }\end{array}$} \\
\hline & $\alpha-\mathrm{COO}^{-}$ & $\alpha-\mathrm{NH}_{3}{ }^{+}$ & $\gamma-\mathrm{COO}^{-}$ & & \\
\hline $\mathbf{K A 1}^{b}$ & Arg507 $\left(\gamma-\mathrm{GH}^{+}\right)$Thr502 (A-NH) Ser674 (A-NH) & Glu723 $\left(\gamma-\mathrm{COO}^{-}\right)$Gly500 (A-CO) & $\operatorname{Ser675}(\beta-\mathrm{OH} / \mathrm{A}-\mathrm{NH})$ & Tyr473 Glu425 & Thr706 \\
\hline $\mathbf{K A} 2^{b}$ & Arg506 $\left(\gamma\right.$-GH $\left.{ }^{+}\right)$Thr501 (A-NH) Ser673 (A-NH) & Glu722 $\left(\gamma-\mathrm{COO}^{-}\right)$Ala500 (A-CO) & Thr674 $(\beta-\mathrm{OH} / \mathrm{A}-\mathrm{NH})$ & Tyr472 Glu424 & Thr705 \\
\hline iGluR5 & Arg538 $\left(\gamma\right.$-GH $\left.{ }^{+}\right)$Thr533 (A-NH)Ser704 (A-NH) & Glu753 $\left(\gamma-\mathrm{COO}^{-}\right)$Pro531 (A-CO) & Thr705 ( $\beta$-OH/A-NH) & Tyr504 Glu456 & $\operatorname{Ser} 736$ \\
\hline iGluR $6^{b}$ & Arg523 $\left(\gamma-\mathrm{GH}^{+}\right)$Ala518 (A-NH) Ala689 (A-NH) & Glu738 $\left(\gamma-\mathrm{COO}^{-}\right)$Pro516 (A-CO) & Thr690 $(\beta-\mathrm{OH} / \mathrm{A}-\mathrm{NH})$ & Tyr488 Glu440 & Asn 721 \\
\hline iGluR7 $^{b}$ & $\operatorname{Arg525}\left(\gamma-\mathrm{GH}^{+}\right)$Thr520 (A-NH) Ala691 (A-NH) & Glu740 $\left(\gamma-\mathrm{COO}^{-}\right)$Pro518 (A-CO) & Thr692 ( $\beta-\mathrm{OH} / \mathrm{A}-\mathrm{NH})$ & Tyr491 Glu443 & Asn 723 \\
\hline
\end{tabular}

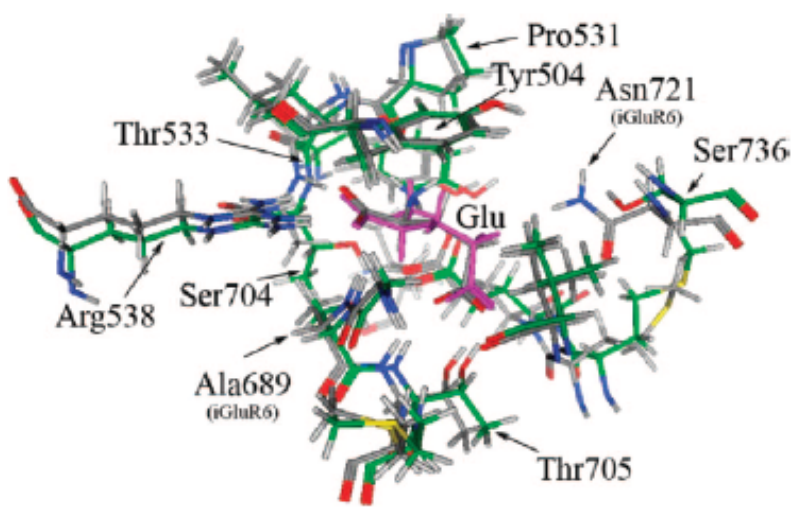

Figure 2. Superimposition of the binding pockets of rat iGluR5 (amino acid residues in green; Glu ligand in pink; PDB code: ltxf) and rat iGluR6 (amino acid residues in type code; Glu ligand in type code; PDB code: 1s50). See Experimental Section for details. Amino acid residue numbering according to iGluR5 unless otherwise noted.

in the same area of space (see Figure 2 for illustrative example with iGluR5,6) and form a hydrogen bond with the $\gamma$-carboxylate group of a Glu amino acid residue (iGluR5:Glu456; iGluR6: Glu440, for clarity, not shown in Figure 2). Intrinsically, residue Ser736(iGluR5) is less voluminous as compared with residues Thr706(KA1), Thr705(KA2), Asn721(iGluR6), andAsn723(iGluR7). Thus, subtype iGluR5 may accommodate larger substituents in the (2S)-2,4-syn position of Glu, compared to KA1, KA2, iGluR6, and iGluR7.

To address as to what extent residues Ser736(iGluR5), Asn721(iGluR6), and Asn723(iGluR7) play a role in the observed altering of the iGluR5/6/7 subtype selectivity profile of structurally very close Glu analogues $\mathbf{2 e , h}$, we conducted an in silico study using the built-in docking procedure in the comprehensive modeling software package MOE (see Experimental Section for details). We first performed an automated docking (see Experimental Section for details) of methylester $\mathbf{2 e}$, amide $\mathbf{2 g}$, methylamide $\mathbf{2 h}$, and $n$-propylamide $\mathbf{2 i}$ to the full-agonist state of iGluR5 (PDB code: 1txf). The Glu analogues: methylester $\mathbf{2 e}$, amide $\mathbf{2 g}$, and methylamide $\mathbf{2 h}$ are all well accommodated by the iGluR5 subtype, whereas $n$ propylamide analogue $\mathbf{2} \mathbf{i}$ induces severe steric clashes with the iGluR5 protein. These findings correlate well with our experimentally determined binding affinities (Table 2).

To investigate the structural origin underlying the unexpected high binding affinity of methylamide $\mathbf{2 h}$ to iGluR6 (and iGluR7), we performed an automated docking of Glu analogues $2 \mathbf{e}, \mathbf{h}, \mathbf{i}$ into the full-agonist state of the iGluR6 subtype. We were not able to identify successful Glu binding poses for either methylester $\mathbf{2} \mathbf{e}$ or $n$-propylamide $\mathbf{2 i}$, a result that is in agreement with the experimental data (Table 2). In contrast, docking of methylamide $\mathbf{2 h}$ proved to be successful. This is because of the increased steric hindrance (residue Asn721) in iGluR6, forcing the $\mathrm{N}$-methylamide side chain of $\mathbf{2 h}$ upward, which then

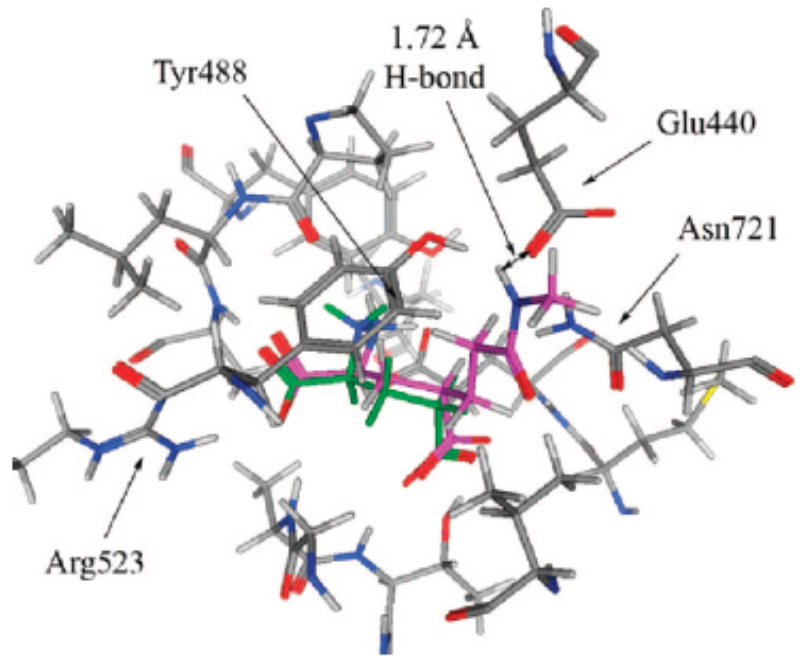

Figure 3. Docking of methylamide $\mathbf{2 h}$ (purple) into full agonist state of the iGluR6 receptor (PDB code:1s50, cocrystallized Glu ligand, in green). The favorable hydrogen bond interaction $(1.72 \AA)$ between the amide-NH of $\mathbf{2 h}$ and the $\gamma$-carboxylate group of residue Glu440, is indicated by the double-headed black arrow.

can participate in a favorable hydrogen bond to the $\gamma$-carboxylate group of residue Glu440 (1.72 ̊, Figure 3). For methylester $\mathbf{2 e}$, such a ligand pose would induce disfavored electron-electron repulsion between the ester-oxygen: $\gamma$-carboxylate of Glu440. On the other hand, a disadvantage to this binding mode of $\mathbf{2 h}$ is its amide-NH close encounter with Tyr488 (approximately $1.36 \AA$ ). However, we are not concerned by this relatively short distance as in silico docking experiments are static representations of dynamic processes and the mobility of residue Tyr 488 is well-documented (see Figure 4). In summary, we thus uphold this amide- $\mathrm{NH}-\gamma$-carboxylate hydrogen bond interaction to play a crucial role as to why methylamide $\mathbf{2 h}$ shows unexpected nanomolar binding affinity to iGluR6 (and iGluR7, as amino acid residues are identical with iGluR6).

While the amide- $\mathrm{NH}_{2}$ of analogue $2 \mathrm{~g}$ is indeed also capable of hydrogen bonding to the $\gamma$-carboxylate group of Glu440, it is nevertheless experimentally shown to be a low affinity ligand at iGluR6,7 (Table 2). The structural difference of $\mathbf{2 g}$, as compared with $\mathbf{2 h}$, is solely the $N$-methyl group. We have investigated this issue in silico by looking at specific favored and disfavored interactions as well as the influence of this group on the low-energy conformation of the Glu analogues $\mathbf{2 g}, \mathbf{h}$. Regrettably, we are not able to put forward conclusive remarks at this point and we believe X-ray crystallographic studies are the method of choice to verify our hypothesis for the high affinity binding of $\mathbf{2 h}$ at iGluR6,7 and eventually guide us to understand why amide $\mathbf{2 g}$ is yet a low affinity ligand at iGluR6,7. This work is ongoing in our laboratories.

We decided to also characterize a small series of standard commercially available iGluR ligands at iGluR7 and for direct 


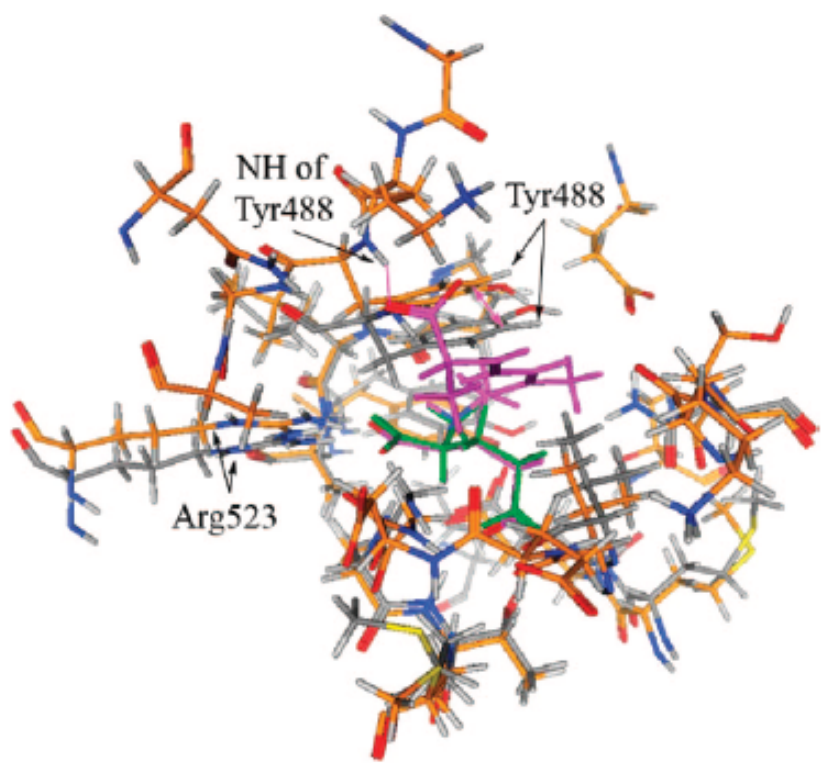

Figure 4. Superimposition of the binding pockets of iGluR6 crystallized with Glu (amino acid residues in type code; Glu ligand in green; PDB code: 1s50) and crystallized with DOMO (amino acid residues in orange; DOMO ligand in pink; PDB code: 1yae). ${ }^{15}$ The carboxylate group of the side chain of DOMO hydrogen bond (pink line) to the backbone $\mathrm{NH}$ of residue Tyr488, thus stabilizing a more voluminous state of the iGluR6 binding pocket (pink arrow: Tyr488 is moved 1.85 A up-and-backward).

comparison also at iGluR5,6 (Table 4 and Figure 1). The binding affinity of KA at iGluR7 $\left(K_{\mathrm{i}}=32.8 \mathrm{nM}\right)$ is comparable with the affinities for iGluR5,6 and KA1,2. In contrast, DHK shows high nanomolar affinity for iGluR7 $\left(K_{\mathrm{i}}=376 \mathrm{nM}\right)$. This is a $20-30$ fold increase in affinity as compared with iGluR5,6 $\left(K_{\mathrm{i}}\right.$ $=8-12 \mu \mathrm{M})$, which indicates that the iGluR7 binding pocket is more voluminous. The sterically more bulky KA like ligand, domoric acid (DOMO), exhibits nanomolar binding affinity for iGluR7 $\left(K_{\mathrm{i}}=3.84 \mathrm{nM}\right)$ comparable with values found for iGluR5,6 $\left(K_{\mathrm{i}}=1-6 \mathrm{nM}\right)$. Quisqualic acid (QUIS) is, however, 10-fold less prone to bind to iGluR7 as compared with iGluR5,6. Finally, the binding affinity for the endogenous ligand of the iGluR7 subtype, Glu, was determined $\left(K_{\mathrm{i}}=494 \mathrm{nM}\right)$, a value comparable to that of iGluR5,6 $\left(K_{\mathrm{i}}=140-331 \mathrm{nM}\right)$. In general, the profile of our pharmacological data for this small series of commercially available iGluR ligands is in agreement with data reported earlier using $\left[{ }^{3} \mathrm{H}\right] \mathrm{KA}$ as the radioligand at cloned iGluR5-7 expressed in HEK293 cells. ${ }^{16}$

\section{Conclusion}

In conclusion, we have presented the chemo-enzymatic enantioselective synthesis of five (2S)-2,4-syn-4-substituted Glu analogues $\mathbf{2 a}-\mathbf{c}, \mathbf{e}, \mathbf{f}$ and the subsequent pharmacological evaluation of nine Glu analogues $\mathbf{2} \mathbf{a}-\mathbf{j}$ as potential AMPA, KA, and NMDA ligands in rat synaptosomal binding assays. Furthermore, $\mathbf{2 b}-\mathbf{j}$ were characterized in binding assays at cloned rat KA receptor subtypes iGluR5-7. Methylester $2 \mathbf{e}$ was shown to have high binding affinity (low nanomolar) at iGluR5 with 120 - and 25 -fold selectivity over iGluR6,7, respectively. What was quite unexpected was that fact that methylamide $2 \mathrm{~h}$ proved to be a high affinity ligand at all three subtypes iGluR5-7. We performed an in silico study to address this finding and have put forward a hypothesis as to why this is. In addition, we have presented iGluR7 binding data for a selected series of commercially available iGluR ligands and shown that Glu itself is a ligand at iGluR7 with affinity comparable with values found for iGluR5,6.

\section{Experimental Section}

Chemistry. Melting points were determined on a Reichert hotstage apparatus and are uncorrected. IR spectra were recorded on a Perkin-Elmer 801 spectrophotometer. ${ }^{1} \mathrm{H}$ and ${ }^{13} \mathrm{C}$ NMR spectra were recorded on a Bruker Avance $400 \mathrm{MHz}$ spectrometer. Chemical shifts are reported in ppm $(\delta)$ relative to TMS as internal standard. HRMS were recorded on a q-tof Micromass spectrometer. Optical rotations were determined with a JASCO DIP 370 polarimeter and are reported at the sodium D line $(589 \mathrm{~nm})$. Elemental analyses were performed at the Service Central d'Analyze du CNRS, Solaize, France. Silicagel 60 (Merck, 40-63 $\mu \mathrm{m}$ ) and precoated $\mathrm{F}_{54}$ plates were used for column and TLC chromatographies. All solvents were purified by distillation following usual procedures. Cysteine sulfinic acid was prepared from cystine following a described procedure. ${ }^{19}$ Bovine heart malic dehydrogenase and rabbit muscle lactic dehydrogenase were purchased from Sigma. E. coli AAT was produced and purified following described procedures from overexpressing $E$. coli strains JM103 transformed with pUC119-aspC (AAT), ${ }^{20}$ Enzyme kinetic measurements were performed at $25^{\circ} \mathrm{C}$ in $0.1 \mathrm{M}$ potassium phosphate buffer, $\mathrm{pH} 7.6$, Asp $(40 \mathrm{mM})$, NADH $(0.2 \mathrm{mM})$, ketoacid substrate $(0.1-10 \mathrm{mM})$, AAT (0.05 UI), and malic dehydrogenase (2 UI) in a total volume of $1 \mathrm{~mL}$. Rates were calculated from the OD linear decay at 340 $\mathrm{nm}$ using $\epsilon_{\mathrm{NADH}}=6220 \mathrm{~cm}^{-1} \cdot \mathrm{M}^{-1}$.

The synthesis of $\mathbf{2} \mathbf{g}-\mathbf{j}$ was described previously by us. ${ }^{7}$

Methyl 2-(benzyloxymethyl)acrylate 3b. To a solution of methyl 2-(bromomethyl)acrylate ${ }^{9}(5 \mathrm{~g}, 27.9 \mathrm{mmol})$ and benzyl alcohol $(5.4 \mathrm{~mL}, 51.8 \mathrm{mmol})$ in THF $(5 \mathrm{~mL})$ cooled at $0{ }^{\circ} \mathrm{C}$ was added dropwise a solution of DABCO $(4.37 \mathrm{~g}, 39 \mathrm{mmol})$ in THF $(20 \mathrm{~mL})$. The suspension of white solid was heated at $70{ }^{\circ} \mathrm{C}$ for $24 \mathrm{~h}$. After filtration, the solution was washed with an aqueous $1 \%$ $\mathrm{HCl}$ solution $(2 \times 20 \mathrm{~mL})$, an aqueous saturated $\mathrm{NaHCO}_{3}$ solution $(20 \mathrm{~mL})$, with brine $(20 \mathrm{~mL})$, dried over $\mathrm{MgSO}_{4}$ and concentrated under reduced pressure. Flash-chromatography (eluent, $\mathrm{CH}_{2} \mathrm{Cl}_{2}$ ) afforded $\mathbf{3 b}$ as a colorless liquid $(4.6 \mathrm{~g}, 80 \%$ ). IR (neat film) 1720 , $1637 \mathrm{~cm}^{-1}$. ${ }^{1} \mathrm{H}$ NMR $\left(400 \mathrm{MHz}, \mathrm{CDCl}_{3}\right) \delta 7.24(5 \mathrm{H}, \mathrm{m}), 6.26$ $(1 \mathrm{H}, \mathrm{d}, J=0.8 \mathrm{~Hz}), 5.87(1 \mathrm{H}, \mathrm{d}, J=0.8 \mathrm{~Hz}), 4.52(2 \mathrm{H}, \mathrm{s}), 4.17$ $(3 \mathrm{H}, \mathrm{s}), 3.69(3 \mathrm{H}, \mathrm{s}) .{ }^{13} \mathrm{C}$ NMR $\left(100 \mathrm{MHz}, \mathrm{CDCl}_{3}\right) \delta 166.2,138.2$, $137.6,128.3,127.9,127.5,125.6,72.8,68.5,51.5$.

1-Benzyl-4-methyl Itaconate 3d. A solution of itaconic anhydride $(6 \mathrm{~g}, 53.5 \mathrm{mmol})$ in $\mathrm{MeOH}(27 \mathrm{~mL})$ was refluxed for $30 \mathrm{~h}$. $\mathrm{MeOH}$ was evaporated, and the white residual solid was dissolved intoluene $(40 \mathrm{~mL})$. Tothissolution was added 1,8diazabicyclo[5.4.0]undec7-ene (DBU, $9.0 \mathrm{~mL}, 53.5 \mathrm{mmol}$ ) and then, dropwise, benzylbromide $(6.35 \mathrm{~mL}, 53.5 \mathrm{mmol})$. The reaction mixture was stirred at room temperature for $70 \mathrm{~min}$. The solution was then washed with an aqueous saturated $\mathrm{NaHCO}_{3}$ solution $(20 \mathrm{~mL})$, with brine $(20$ $\mathrm{mL}$ ), dried over $\mathrm{MgSO}_{4}$, and concentrated under reduced pressure to give $3 \mathbf{d}$ isolated as a colorless liquid $(11.8 \mathrm{~g}, 95 \%)$. IR (neat film) $1732,1641 \mathrm{~cm}^{-1} .{ }^{1} \mathrm{H}$ NMR $\left(400 \mathrm{MHz}, \mathrm{CDCl}_{3}\right) \delta 7.35(5 \mathrm{H}$, $\mathrm{m}), 6.39(1 \mathrm{H}, \mathrm{d}, J=0.8 \mathrm{~Hz}) .5 .73(1 \mathrm{H}, \mathrm{td}, J=0.8$ and $1,2 \mathrm{~Hz})$, $5.21(2 \mathrm{H}, \mathrm{s}), 3.64(3 \mathrm{H}, \mathrm{s}), 3.36(2 \mathrm{H}, \mathrm{d}, J=1.2 \mathrm{~Hz}) .{ }^{13} \mathrm{C}$ NMR $(100$ $\left.\mathrm{MHz}, \mathrm{CDCl}_{3}\right) \delta 171.1,165.9,135.8,133.7,128.9,128.5,128.2$, 128.1, 66.8, 52.0, 37.6. HRMS (ES+) $m / z 257.0784\left([\mathrm{M}+\mathrm{Na}]^{+}\right.$, $\mathrm{C}_{13} \mathrm{H}_{14} \mathrm{NaO}_{4}$ requires 257.0790). Anal. $\left(\mathrm{C}_{13} \mathrm{H}_{14} \mathrm{O}_{4}\right): \mathrm{C}, \mathrm{H}, \mathrm{N}$.

1-Benzyl-5-methyl 2-methylideneglutarate 3e. To a solution of benzyl 2-(hydroxymethyl)acrylate ${ }^{10}(5 \mathrm{~g}, 26.0 \mathrm{mmol})$ in toluene $(60 \mathrm{~mL})$ were added trimethyl orthoacetate $(6.6 \mathrm{~mL}, 52.0 \mathrm{mmol})$ and propionic acid $(0.2 \mathrm{~mL}, 2.6 \mathrm{mmol})$. The reaction mixture was heated at $100{ }^{\circ} \mathrm{C}$ for $1.5 \mathrm{~h}$ before methanol was slowly removed by azeotropic distillation. The solution was concentrated under reduced pressure. Flash-chromatography (eluent, cyclohexaneAcOEt, 8:2, v/v) afforded 3e isolated as colorless liquid. (4.71 g, $73 \%$ ). IR (neat film) $1738,1720,1632 \mathrm{~cm}^{-1} \cdot{ }^{1} \mathrm{H}$ NMR $(400 \mathrm{MHz}$, $\left.\mathrm{CDCl}_{3}\right) \delta 7.38(5 \mathrm{H}, \mathrm{m}), 6.27(1 \mathrm{H}, \mathrm{s}), 5.65(1 \mathrm{H}, \mathrm{s}), 5.23(2 \mathrm{H}, \mathrm{s})$, $3.69(3 \mathrm{H}, \mathrm{s}), 2.69(2 \mathrm{H}, \mathrm{t}, J=7.5 \mathrm{~Hz}), 2.54(2 \mathrm{H}, \mathrm{t}, J=7.5 \mathrm{~Hz})$. ${ }^{13} \mathrm{C}$ NMR (100 MHz, $\left.\mathrm{CDCl}_{3}\right) \delta 173.1,166.4,138.8,135.9,128.6$, $128.2,128.1,126.3,66.5,51.6,32.9,27.3$. HRMS (ES+) $m / z$ 
Table 4. Binding Affinities of Commercially Available Standard iGluR Ligands: KA, DHK, DOMO, and QUIS at Cloned Homomeric Rat KA1,2 and Homomeric Rat iGluR5-7 Subtypes ${ }^{a}$

\begin{tabular}{|c|c|c|c|c|c|}
\hline compound & rat KA1 $K_{\mathrm{i}}(\mathrm{nM})$ & rat KA2 $K_{\mathrm{i}}(\mathrm{nM})$ & rat iGluR5 $K_{\mathrm{i}}(\mathrm{nM})$ & rat iGluR6 $K_{\mathrm{i}}(\mathrm{nM})$ & rat iGluR7 $K_{\mathrm{i}}(\mathrm{nM})$ \\
\hline KA & $4.7^{b}$ & $15^{\circ}$ & $\begin{array}{l}75.9 \\
{[7.15 \pm 0.08]}\end{array}$ & $\begin{array}{l}12.7 \\
{[7.91 \pm 0.06]}\end{array}$ & $\begin{array}{l}32.8 \\
{[8.42 \pm 0.04]}\end{array}$ \\
\hline DHK & nd & nd & $\begin{array}{l}8180 \\
{[5.09 \pm 0.02]}\end{array}$ & $\begin{array}{l}12300 \\
{[4.92 \pm 0.05]}\end{array}$ & $\begin{array}{l}376 \\
{[6.44 \pm 0.07]}\end{array}$ \\
\hline DOMO & $40^{b}$ & nd & $\begin{array}{l}1.11 \\
{[8.97 \pm 0.09]}\end{array}$ & $\begin{array}{l}6.04 \\
{[8.24 \pm 0.08]}\end{array}$ & $\begin{array}{l}3.84 \\
{[8.42 \pm 0.04]}\end{array}$ \\
\hline QUIS & nd & nd & $\begin{array}{l}171 \\
{[6.77 \pm 0.01]}\end{array}$ & $\begin{array}{l}134 \\
{[6.88 \pm 0.05]}\end{array}$ & $\begin{array}{l}1670 \\
{[5.86 \pm 0.13]}\end{array}$ \\
\hline Glu & nd & nd & $\begin{array}{l}140 \\
{[6.86 \pm 0.01]}\end{array}$ & $\begin{array}{l}331 \\
{[6.48 \pm 0.02]}\end{array}$ & $\begin{array}{l}494 \\
{[6.31 \pm 0.03]}\end{array}$ \\
\hline$(2 S, 4 R)$-Me-Glu & nd & nd & {$[9.18 \pm 0.02]$} & $\begin{array}{l}17.0 \\
{[7.83 \pm 0.09]}\end{array}$ & $\begin{array}{l}5.69 \\
{[8.33 \pm 0.10]}\end{array}$ \\
\hline
\end{tabular}

${ }^{a}$ Mean value from at least three experiments conducted in triplicate is shown $\left[\mathrm{p} K_{\mathrm{i}}(\mathrm{M}) \pm\right.$ S.E.M.]. nd $=$ no data available. ${ }^{b}$ Value taken from ref 17. ${ }^{\circ}$ Value taken from reference 18.

$271.0959\left([\mathrm{M}+\mathrm{Na}]^{+}, \mathrm{C}_{14} \mathrm{H}_{16} \mathrm{NaO}_{4}\right.$ requires 271.0946). Anal. $\left(\mathrm{C}_{14} \mathrm{H}_{16} \mathrm{O}_{4}\right): \mathrm{C}, \mathrm{H}, \mathrm{N}$.

General Procedure for the Synthesis of $4 b-e$. To a solution of acrylate $3 \mathbf{b}-\mathbf{e}(20 \mathrm{mmol})$ in $\mathrm{MeOH}(\mathbf{3 b}$ and $\mathbf{3 c})$ or DMSO (3d and $3 \mathrm{e})(40 \mathrm{~mL})$ were added $\mathrm{KF}(3.5 \mathrm{~g}, 60 \mathrm{mmol})$ and methyl or benzyl acetoacetate $(30 \mathrm{mmol})$. The reaction mixture was heated at $65{ }^{\circ} \mathrm{C}$ for $1-16 \mathrm{~h}$ until the disappearance of acrylate 3 . The reaction mixture was then diluted with brine $(40 \mathrm{~mL})$ and extracted with AcOEt $(4 \times 50 \mathrm{~mL})$. The combined organic layers were dried over $\mathrm{MgSO}_{4}$ and concentrated under reduced pressure. Flash chromatography (eluent, cyclohexane-AcOEt, 8:2 or $\mathrm{CH}_{2} \mathrm{Cl}_{2}-\mathrm{MeOH}, 99: 1$ for $\mathbf{4 b}$, v/v) afforded $\mathbf{4 b}-\mathbf{e}$ as colorless liquids and as 1:1 mixtures of diastereomers.

Dimethyl 2-Acetyl-4-(benzyloxymethyl)glutarate $4 \mathrm{~b}$. Yield 95\%. IR (neat film) $1738 \mathrm{~cm}^{-1}$. ${ }^{1} \mathrm{H}$ NMR $\left(400 \mathrm{MHz}, \mathrm{CDCl}_{3}\right) \delta$ $7.33(2 \times 5 \mathrm{H}, \mathrm{m}), 4.49(2 \times 2 \mathrm{H}, \mathrm{m}), 3.73(3 \mathrm{H}, \mathrm{s}), 3.70(3 \mathrm{H}, \mathrm{s})$, $3.69(2 \times 3 \mathrm{H}, \mathrm{s}), 3.76-3.57(2 \times 3 \mathrm{H}, \mathrm{m}), 2.69(2 \times 1 \mathrm{H}, \mathrm{m}), 2.24$ $(3 \mathrm{H}, \mathrm{s}), 2.22(3 \mathrm{H}, \mathrm{s}), 2.30-2.05(2 \times 2 \mathrm{H}, \mathrm{m}) .{ }^{13} \mathrm{C}$ NMR $(100 \mathrm{MHz}$, $\left.\mathrm{CDCl}_{3}\right) \delta 202.5,173.7,169.5,137.8,128.4,127.7,127.6,73.1$, $70.7,70.3,57.2,56.8,52.5,51.9,43.6,43.5,29.5,29.0,26.9,26.8$. HRMS (ES+) $m / z \quad 345.1306\left([\mathrm{M}+\mathrm{Na}]^{+}, \mathrm{C}_{17} \mathrm{H}_{22} \mathrm{NaO}_{6}\right.$ requires 345.1314)

Trimethyl 5-Oxohexane-1,2,4-tricarboxylate 4c. Yield 78\%. IR (neat film) $1737 \mathrm{~cm}^{-1}$. ${ }^{1} \mathrm{H}$ NMR (400 MHz, $\left.\mathrm{CDCl}_{3}\right) \delta 3.72$ $(3 \mathrm{H}, \mathrm{s}), 3.69(3 \mathrm{H}, \mathrm{s}), 3.66(3 \mathrm{H}, \mathrm{s}), 3.63(2 \times 3 \mathrm{H}, \mathrm{s}), 3.63-3.57(2$ $\times 1 \mathrm{H}, \mathrm{m}), 2.75(2 \times 1 \mathrm{H}, \mathrm{m}), 2.75-2.35(2 \times 2 \mathrm{H}, \mathrm{m}), 2.24(3 \mathrm{H}$, s), $2.21(3 \mathrm{H}, \mathrm{s}), 2.15-2.00(2 \times 2 \mathrm{H}, \mathrm{m}) .{ }^{13} \mathrm{C}$ NMR $(100 \mathrm{MHz}$, $\left.\mathrm{CDCl}_{3}\right) \delta 202.0,201.8,174.2,171.7,169.4,169.3,57.3,56.6,52.6$, $52.0,51.8,51.7,39.2,39.0,36.3,36.0,29.8,29.7,29.5,29.0$. HRMS (ES+) $m / z 297.0935\left([\mathrm{M}+\mathrm{Na}]^{+}, \mathrm{C}_{12} \mathrm{H}_{18} \mathrm{NaO}_{7}\right.$ requires 297.0950).

2,4-Dibenzyl-1-methyl 5-oxohexane-1,2,4-tricarboxylate 4d. Yield $66 \%$. IR (neat film) $1745,1712 \mathrm{~cm}^{-1}{ }^{1} \mathrm{H}$ NMR $(400 \mathrm{MHz}$, $\left.\mathrm{CDCl}_{3}\right) \delta 7.35(4 \times 5 \mathrm{H}, \mathrm{m}), 5.12(4 \times 2 \mathrm{H}, \mathrm{m}), 3.62(2 \times 1 \mathrm{H}, \mathrm{m})$, $3.60(2 \times 3 \mathrm{H}, \mathrm{s}), 2.84(2 \times 1 \mathrm{H}, \mathrm{m}), 2.72(2 \times 1 \mathrm{H}, \mathrm{m}), 2.48(2 \times$ $1 \mathrm{H}, \mathrm{m}), 2.13(3 \mathrm{H}, \mathrm{s}), 2.10(3 \mathrm{H}, \mathrm{s}), 2.20-2.00(2 \times 2 \mathrm{H}, \mathrm{m}) .{ }^{13} \mathrm{C}$ $\operatorname{NMR}\left(100 \mathrm{MHz}, \mathrm{CDCl}_{3}\right) \delta 201.9,201.7,173.6,171.6,168.8,168.6$, $135.6,135.1,128.7,128.6,128.4,128.2,128.1,128.0,67.4,66.8$, $57.4,56.6,51.8,39.3,39.1,36.5,36.1,29.7,29.6,29.5,29.0$. HRMS $(\mathrm{ES}+) m / z 449.1566\left([\mathrm{M}+\mathrm{Na}]^{+}, \mathrm{C}_{24} \mathrm{H}_{26} \mathrm{NaO} 7\right.$ requires 449.1576$)$.

3,5-Dibenzyl-1-methyl 6-oxoheptane-1,3,5-tricarboxylate 4e. Yield $75 \%$. IR (neat film) $1737 \mathrm{~cm}^{-1}$. ${ }^{1} \mathrm{H}$ NMR $\left(400 \mathrm{MHz}, \mathrm{CDCl}_{3}\right.$ ) $\delta 7.35(4 \times 5 \mathrm{H}, \mathrm{m}), 5.05(4 \times 2 \mathrm{H}, \mathrm{m}), 3.56(2 \times 3 \mathrm{H}, \mathrm{s}), 3.43(2$ $\times 1 \mathrm{H}, \mathrm{m}), 2.34(2 \times 1 \mathrm{H}, \mathrm{m}), 2.02(2 \times 3 \mathrm{H}, \mathrm{s}), 2.25-1.70(2 \times$ $6 \mathrm{H}, \mathrm{m}) .{ }^{13} \mathrm{C}$ NMR $\left(100 \mathrm{MHz}, \mathrm{CDCl}_{3}\right) \delta 202.0,201.8,174.3,173.0$, $168.9,168.7,135.7,135.2,135.1,128.6,128.5,128.4,67.31,67.28$, 66.6, 57.4, 56.6, 51.6, 42.5, 42.3, 31.4, 31.3, 29.8, 29.0, 27.5, 27.1. HRMS (ES+) $m / z 463.1724\left([\mathrm{M}+\mathrm{Na}]^{+}, \mathrm{C}_{25} \mathrm{H}_{28} \mathrm{NaO}_{7}\right.$ requires 463.1733).

General Procedure for the Synthesis of $5 b-e$. To a solution of $4 \mathbf{b}-\mathbf{e}(10 \mathrm{mmol})$ in anhydrous pyridine $(20 \mathrm{~mL})$ was added acetyl chloride $(1.1 \mathrm{~mL}, 15 \mathrm{mmol})$. The mixture was stirred at room temperature for $3-48 \mathrm{~h}$ until the complete disappearance of $\mathbf{4 b}-\mathbf{e}$. The solution was then diluted with $\mathrm{Et}_{2} \mathrm{O}(50 \mathrm{~mL})$, washed with an aqueous saturated solution of $\mathrm{CuSO}_{4}(2 \times 50 \mathrm{~mL})$, with water $(50$ $\mathrm{mL}$ ), dried over $\mathrm{MgSO}_{4}$ and concentrated under reduced pressure. Flash chromatography (eluent, cyclohexane-AcOEt, 8:2, v/v) afforded $\mathbf{5 b}-\mathbf{e}$ isolated as colorless liquids and as a single stereomer.

Dimethyl 2-(1-Acetoxyethylidene)-4-(benzyloxymethyl) Glutarate 5b. Yield $64 \%$. IR (neat film) $1762,1723,1653 \mathrm{~cm}^{-1} .{ }^{1} \mathrm{H}$ NMR $\left(400 \mathrm{MHz}, \mathrm{CDCl}_{3}\right) \delta 7.31(5 \mathrm{H}, \mathrm{m}), 4.47(2 \mathrm{H}, \mathrm{m}), 3.73(3 \mathrm{H}$, s), $3.66(3 \mathrm{H}, \mathrm{s}), 3.60(1 \mathrm{H}, \mathrm{dd}, J=7.2$ and $9.0 \mathrm{~Hz}), 3.52(1 \mathrm{H}$, dd, $J=5.50$ and $9.2 \mathrm{~Hz}), 2.81(1 \mathrm{H}, \mathrm{m}), 2.57(2 \mathrm{H}, \mathrm{m}), 2.28(3 \mathrm{H}, \mathrm{s})$, $2.10(3 \mathrm{H}, \mathrm{s}) .{ }^{13} \mathrm{C} \mathrm{NMR}\left(100 \mathrm{MHz}, \mathrm{CDCl}_{3}\right) \delta 174.1,168.1,167.5$, $158.7,138.1,128.3,127.5,119.2,73.0,70.1,51.8,45.0,26.4,20.8$, 19.6. HRMS (ES+) $\mathrm{m} / \mathrm{z} 387.1427\left([\mathrm{M}+\mathrm{Na}]^{+}, \mathrm{C}_{19} \mathrm{H}_{24} \mathrm{NaO}_{7}\right.$ requires 387.1420 ).

Trimethyl 5-Acetoxyhex-4-ene-1,2,4-tricarboxylate 5c. Yield $86 \%$. IR (neat film) $1760,1732,1651 \mathrm{~cm}^{-1} .{ }^{1} \mathrm{H}$ NMR $(400 \mathrm{MHz}$, $\left.\mathrm{CDCl}_{3}\right) \delta 3.73(3 \mathrm{H}, \mathrm{s}), 3.64(3 \mathrm{H}, \mathrm{s}), 3.62(3 \mathrm{H}, \mathrm{s}), 2.92(1 \mathrm{H}, \mathrm{m})$, $2.62(2 \mathrm{H}, \mathrm{m}), 2.43(2 \mathrm{H}, \mathrm{m}), 2.26(3 \mathrm{H}, \mathrm{s}), 2.16(3 \mathrm{H}, \mathrm{s}) .{ }^{13} \mathrm{C} \mathrm{NMR}$ $\left(100 \mathrm{MHz}, \mathrm{CDCl}_{3}\right) \delta 174.6,172.1,167.9,167.2,159.2,118.6,51.9$, $51.8,51.7,40.2,35.0,29.1,20.8,19.6$. HRMS (ES+) $\mathrm{m} / \mathrm{z} 339.1057$ $\left([\mathrm{M}+\mathrm{Na}]^{+}, \mathrm{C}_{14} \mathrm{H}_{20} \mathrm{NaO}_{8}\right.$ requires 339.1056$)$.

2,4-Dibenzyl-1-methyl 5-acetoxyhex-4-ene-1,2,4-tricarboxylate 5d. Yield $86 \%$. IR (neat film) $1760,1732,1650 \mathrm{~cm}^{-1} \cdot{ }^{1} \mathrm{H}$ NMR $\left(400 \mathrm{MHz}, \mathrm{CDCl}_{3}\right) \delta 7.32(10 \mathrm{H}, \mathrm{m}), 5.18(2 \mathrm{H}, \mathrm{s}), 5.08(2 \mathrm{H}$, s), $3.58(3 \mathrm{H}, \mathrm{s}), 3.01(1 \mathrm{H}, \mathrm{m}), 2.68(2 \mathrm{H}, \mathrm{m}), 2.46(2 \mathrm{H}, \mathrm{m}), 2.26$ $(3 \mathrm{H}, \mathrm{s}), 2.14(3 \mathrm{H}, \mathrm{s}){ }^{13} \mathrm{C}$ NMR $\left(100 \mathrm{MHz}, \mathrm{CDCl}_{3}\right) \delta 174.5,173.9$, $168.0,166.6,159.5,135.9,135.6,128.6,128.5,128.3,128.1,118.8$, $66.8,66.6,51.7,40.4,35.1,29.3,20.8,19.7$. HRMS (ES+) $\mathrm{m} / \mathrm{z}$ $491.1692\left(\left[\mathrm{M}+\mathrm{Na}^{+}, \mathrm{C}_{26} \mathrm{H}_{28} \mathrm{NaO}_{8}\right.\right.$ requires 491.1682$)$.

3,5-Dibenzyl-1-methyl 6-acetoxyhept-5-ene-1,3,5-tricarboxylate 5e. Yield 91\%. IR (neat film) $1758,1736,1651 \mathrm{~cm}^{-1}$. ${ }^{1} \mathrm{H}$ NMR $\left(400 \mathrm{MHz} \mathrm{CDCl}_{3}\right) \delta 7.32(10 \mathrm{H}, \mathrm{m}), 5.17(2 \mathrm{H}, \mathrm{m}), 5.05(2 \mathrm{H}, \mathrm{s})$, $3.62(3 \mathrm{H}, \mathrm{s}), 2.68(1 \mathrm{H}, \mathrm{dd}, J=8.2$ and $13.1 \mathrm{~Hz}), 2.59(1 \mathrm{H}, \mathrm{m})$, $2.43(1 \mathrm{H}, \mathrm{dd}, J=6.1$ and $13.1 \mathrm{~Hz}), 2.26(3 \mathrm{H}, \mathrm{s}), 2.22(2 \mathrm{H}, \mathrm{m})$, $2.15(3 \mathrm{H}, \mathrm{s}), 1.95-1.75(2 \mathrm{H}, \mathrm{m}),{ }^{13} \mathrm{C}$ NMR $\left(100 \mathrm{MHz}, \mathrm{CDCl}_{3}\right) \delta$ $174.6,173.1,168.0,166.7,159.0,135.9,135.7,128.6,128.5,128.3$, $128.2,119.2,66.7,66.4,51.6,43.9,31.6,30.0,27.0,20.8,19.7$. HRMS (ES+) $m / z 505.1847\left([\mathrm{M}+\mathrm{Na}]^{+}, \mathrm{C}_{27} \mathrm{H}_{30} \mathrm{NaO}_{8}\right.$ requires 505.1838).

General Ozonolysis Procedure for the Synthesis of 6c-e. A solution of enol acetate $\mathbf{5 c}-\mathbf{e}(5 \mathrm{mmol})$ in anhydrous $\mathrm{CH}_{2} \mathrm{Cl}_{2}(30$ $\mathrm{mL}$ ) was treated at $-70{ }^{\circ} \mathrm{C}$ with a mixture of $\mathrm{O}_{2}$ and $\mathrm{O}_{3}$ at a rate of $10 \mathrm{~L} / \mathrm{h}$ until saturation (blue coloration of the solution). After $30 \mathrm{~min}$, the excess ozone was eliminated by oxygen bubbling. Dimethyl sulfide $(0.55 \mathrm{~mL}, 7.5 \mathrm{mmol})$ was added, and the reaction mixture was allowed to warm to room temperature. The solution was washed with water $(20 \mathrm{~mL})$, brine $(20 \mathrm{~mL})$, dried over $\mathrm{MgSO}_{4}$ and concentrated under reduced pressure. Flash-chromatography (eluent, cyclohexane-AcOEt, 8:3, v/v or AcOEt for $6 \mathrm{c}$ ) afforded $\mathbf{6 c}-\mathbf{e}$ as colorless liquids.

Trimethyl 4-Oxobutane-1,2,4-tricarboxylate 6c. Yield 72\%; IR (neat film) $1732 \mathrm{~cm}^{-1} .{ }^{1} \mathrm{H}$ NMR $\left(400 \mathrm{MHz}, \mathrm{CDCl}_{3}\right) \delta 3.84$ $(3 \mathrm{H}, \mathrm{s}), 3.65(2 \times 3 \mathrm{H}, \mathrm{s}), 3.35(2 \mathrm{H}, \mathrm{m}) 3.02(1 \mathrm{H}, \mathrm{m}), 2.73(1 \mathrm{H}$, 
dd, $J=5.8$ and $16.8 \mathrm{~Hz}), 2.60(1 \mathrm{H}, \mathrm{dd}, J=6.8$ and $16.8 \mathrm{~Hz}){ }^{13} \mathrm{C}$ NMR $\left(100 \mathrm{MHz}, \mathrm{CDCl}_{3}\right) \delta 191.2,173.2,171.6,160.7,53.1,52.4$, $51.9,39.9,36.2,34.8$. HRMS (ES+) $m / z 269.0634\left([\mathrm{M}+\mathrm{Na}]^{+}\right.$, $\mathrm{C}_{10} \mathrm{H}_{14} \mathrm{NaO}_{7}$ requires 269.0637$)$. Anal. $\left(\mathrm{C}_{10} \mathrm{H}_{14} \mathrm{O}_{7}\right): \mathrm{C}, \mathrm{H}, \mathrm{N}$.

2,4-Dibenzyl-1-methyl 4-oxobutane-1,2,4-tricarboxylate 6d. Yield $73 \%$; IR (neat film) $1736 \mathrm{~cm}^{-1} .{ }^{1} \mathrm{H}$ NMR $\left(400 \mathrm{MHz}, \mathrm{CDCl}_{3}\right)$ d $7.34(10 \mathrm{H}, \mathrm{m}), 5.27(2 \mathrm{H}, \mathrm{s}), 5.12(2 \mathrm{H}, \mathrm{m}), 3.63(3 \mathrm{H}, \mathrm{s}), 3.42$ $(2 \mathrm{H}, \mathrm{m}) 3.09(1 \mathrm{H}, \mathrm{m}), 2.78(1 \mathrm{H}, \mathrm{dd}, J=5.6$ and $16.8 \mathrm{~Hz}), 2.64$ $(1 \mathrm{H}, \mathrm{dd}, J=6.4$ and $16.8 \mathrm{~Hz}),{ }^{13} \mathrm{C} \mathrm{NMR}\left(100 \mathrm{MHz}, \mathrm{CDCl}_{3}\right) \delta$ $191.5,172.7,171.6,160.1,135.4,134.4,128.8,128.7,128.6,128.3$, $128.2,68.1,67.1,51.9,40.0,36.4,34.9$. HRMS (ES+) $\mathrm{m} / \mathrm{z} 421.1270$ $\left([\mathrm{M}+\mathrm{Na}]^{+}, \mathrm{C}_{22} \mathrm{H}_{22} \mathrm{NaO}_{7}\right.$ requires 421.1263$)$. Anal. $\left(\mathrm{C}_{22} \mathrm{H}_{22} \mathrm{O}_{7}\right)$ : C, $\mathrm{H}, \mathrm{N}$.

1,3-Dibenzyl-5-methyl 1-oxopentane-1,3,5-tricarboxylate 6e. Yield 59\%; IR (neat film) $1736 \mathrm{~cm}^{-1} \cdot{ }^{1} \mathrm{H}$ NMR ( $400 \mathrm{MHz}^{-\mathrm{CDCl}_{3}}$ ) $\delta 7.31(10 \mathrm{H}, \mathrm{m}), 5.24(2 \mathrm{H}, \mathrm{s}), 5.08(2 \mathrm{H}, \mathrm{s}), 3.62(3 \mathrm{H}, \mathrm{s}), 3.30(2 \mathrm{H}$, dd, $J=8.4$ and $18.1 \mathrm{~Hz}), 2.98(1 \mathrm{H}, \mathrm{m}), 2.93(1 \mathrm{H}$, dd, $J=4.7$ and $18.1 \mathrm{~Hz}), 2.33(2 \mathrm{H}, \mathrm{m}), 2.05-1.80(2 \mathrm{H}, \mathrm{m}) .{ }^{13} \mathrm{C}$ NMR $(100 \mathrm{MHz}$, $\left.\mathrm{CDCl}_{3}\right) \delta 191.7,173.6,172.9,160.1,135.5,134.3,128.8,128.7$, $128.6,128.3,128.2,68.1,66.9,51.7,40.8,39.2,31.3,26.6$. HRMS $(\mathrm{ES}+) m / z 435.1423\left([\mathrm{M}+\mathrm{Na}]^{+}, \mathrm{C}_{23} \mathrm{H}_{24} \mathrm{NaO}_{7}\right.$ requires 435.1420$)$. Anal. $\left(\mathrm{C}_{23} \mathrm{H}_{24} \mathrm{O}_{7}\right): \mathrm{C}, \mathrm{H}, \mathrm{N}$

Dimethyl 2-(Benzyloxymethyl)-4-oxoglutarate $6 \mathrm{~b}$. To a solution of $\mathbf{5 b}(0.83 \mathrm{~g}, 2.3 \mathrm{mmol})$ in $\mathrm{CHCl}_{3}(8 \mathrm{~mL})$ were added $\mathrm{CH}_{3} \mathrm{CN}$ $(8 \mathrm{~mL}), \mathrm{H}_{2} \mathrm{O}(15 \mathrm{~mL}), \mathrm{NaIO}_{4}(1.95 \mathrm{~g}, 9.1 \mathrm{mmol})$, and $\mathrm{RuO}_{2}(60$ $\mathrm{mg}, 0.45 \mathrm{mmol}$ ). The mixture was stirred vigorously at room temperature for $4 \mathrm{~h}$. After filtration through celite, the organic layer was isolated and the aqueous layer extracted with $\mathrm{CHCl}_{3}(10 \mathrm{~mL})$. The combined organic layers were dried over $\mathrm{MgSO}_{4}$ and concentrated under reduced pressure. Flash chromatography (eluent, cyclohexane-AcOEt, 7:3, v/v) afforded $6 \mathbf{b}$ as a colorless liquid $(0.29 \mathrm{~g}, 43 \%)$. IR (neat film) $1736 \mathrm{~cm}^{-1}$. ${ }^{1} \mathrm{H}$ NMR $(400 \mathrm{MHz}$, $\left.\mathrm{CDCl}_{3}\right) \delta 7.31(5 \mathrm{H}, \mathrm{m}), 4.50(2 \mathrm{H}, \mathrm{s}), 3.86(3 \mathrm{H}, \mathrm{s}), 3.72(3 \mathrm{H}, \mathrm{s})$, $3.71(2 \mathrm{H}, \mathrm{m}), 3.44(1 \mathrm{H}, \mathrm{dd}, J=8.1$ and $18.1 \mathrm{~Hz}), 3.31(1 \mathrm{H}, \mathrm{m})$, $3.10(2 \mathrm{H}$, dd, $J=5.3$ and $18.1 \mathrm{~Hz}) .{ }^{13} \mathrm{C} \mathrm{NMR}\left(100 \mathrm{MHz}, \mathrm{CDCl}_{3}\right)$ $\delta 191.9,172.5,160.9,137.6,128.4,127.8,127.6,73.1,69.4,53.0$, $52.2,41.2,38.1$. HRMS (ES+) $m / z 317.1008\left(\left[\mathrm{M}+\mathrm{Na}^{+}\right.\right.$, $\mathrm{C}_{15} \mathrm{H}_{18} \mathrm{NaO}_{6}$ requires 317.1001$)$. Anal. $\left(\mathrm{C}_{15} \mathrm{H}_{18} \mathrm{O}_{6}\right): \mathrm{C}, \mathrm{H}, \mathrm{N}$.

Dimethyl 2-(Hydroxymethyl)-4-oxoglutarate 6a. To a solution of $\mathbf{5 b}(0.14 \mathrm{~g}, 0.47 \mathrm{mmol})$ in $\mathrm{MeOH}(8 \mathrm{~mL})$ was added $10 \% \mathrm{Pd} / \mathrm{C}$ (20 mg). The solution was degassed under reduced pressure and then flushed with hydrogen using a balloon. The suspension was stirred at room temperature for $1 \mathrm{~h}$ before filtration on a $0.2 \mu \mathrm{m}$ membrane and concentration under reduced pressure. Flash chromatography (eluent, cyclohexane-AcOEt, 5:5, v/v) afforded 6a as a colorless liquid $(93 \mathrm{mg}, 97 \%$ ). As shown by NMR, 6a exists in solution as a 1:1 mixture of hemiacetals. IR (neat film) 3458,1737 $\mathrm{cm}^{-1} .{ }^{1} \mathrm{H}$ NMR $\left(400 \mathrm{MHz}, \mathrm{CDCl}_{3}\right) \delta 4.44(1 \mathrm{H}, \mathrm{s}), 4.30(1 \mathrm{H}, \mathrm{t}, J$ $=8.4 \mathrm{~Hz}), 4.29(1 \mathrm{H}, \mathrm{dd}, J=6.3$ and $8.7 \mathrm{~Hz}), 4.17(1 \mathrm{H}, \mathrm{t}, J=8.6$ $\mathrm{Hz}), 4.15(1 \mathrm{H}, \mathrm{t}, J=8.5 \mathrm{~Hz}), 4.12(1 \mathrm{H}, \mathrm{s}), 3.81(2 \times 3 \mathrm{H}, \mathrm{s}), 3.73$ $(3 \mathrm{H}, \mathrm{s}), 3.71(3 \mathrm{H}, \mathrm{s}), 3.43(1 \mathrm{H}, \mathrm{m}), 3.29(1 \mathrm{H}, \mathrm{m}), 2.71(1 \mathrm{H}, \mathrm{dd}, J$ $=9.4$ and $13.8 \mathrm{~Hz}), 2.68(1 \mathrm{H}, \mathrm{dd}, J=9.2$ and $13.9 \mathrm{~Hz}), 2.42(1 \mathrm{H}$, dd. $J=5.7$ and $13.7 \mathrm{~Hz}), 2.32(1 \mathrm{H}, \mathrm{dd}, J=8.4$ and $13.1 \mathrm{~Hz}) .{ }^{13} \mathrm{C}$ NMR $\left(100 \mathrm{MHz}, \mathrm{CDCl}_{3}\right) \delta 173.4,172.7,170.5,170.2,102.6,102.2$, $70.4,53.3,53.2,52.5,52.3,43.6,42.7,38.3$. HRMS (ES+) $\mathrm{m} / \mathrm{z}$ $227.0536\left([\mathrm{M}+\mathrm{Na}]^{+}, \mathrm{C}_{8} \mathrm{H}_{12} \mathrm{NaO}_{6}\right.$ requires 227.0532). Anal. $\left(\mathrm{C}_{8} \mathrm{H}_{12} \mathrm{O}_{6}\right): \mathrm{C}, \mathrm{H}, \mathrm{N}$.

General Procedure for the Synthesis of Lithium Oxoglutarates $1 \mathrm{a}, 1 \mathrm{~b}$, and $1 \mathrm{c}$. To a solution of $6 \mathrm{a}, 6 \mathrm{~b}$, or $6 \mathrm{c}(1 \mathrm{mmol})$ in $\mathrm{MeOH}(5$ or $7.5 \mathrm{~mL}$ for $6 \mathrm{c}$ ) was added dropwise a $0.4 \mathrm{M}$ solution of $\mathrm{LiOH}(5.25 \mathrm{~mL}, 2.1 \mathrm{mmol}$ or $7.75 \mathrm{~mL}, 3.1 \mathrm{mmol}$ for $6 \mathrm{c})$. The mixture was stirred at room temperature for $24 \mathrm{~h}$. After evaporation of $\mathrm{MeOH}$, the $\mathrm{pH}$ of the aqueous solution was adjusted to 7.6 by addition of dowex $50 \mathrm{WX} 8 \mathrm{resin}\left(\mathrm{H}^{+}\right.$form). The resin was removed by filtration before evaporation of the water under reduced pressure. $\mathbf{1 a}, \mathbf{1 b}$, and $\mathbf{1 c}$ were isolated in quantitative yields as white solids.

Dilithium 2-(Hydroxymethyl)-4-oxoglutarate 1a. ${ }^{1} \mathrm{H}$ NMR $\left(400 \mathrm{MHz}, \mathrm{D}_{2} \mathrm{O}\right) \delta 4.40(1 \mathrm{H}, \mathrm{t}, J=8.6 \mathrm{~Hz}), 4.34(1 \mathrm{H}, \mathrm{t}, J=8.3$ $\mathrm{Hz}), 4.24(1 \mathrm{H}, \mathrm{dd}, J=6.5$ and $8.4 \mathrm{~Hz}), 4.13(1 \mathrm{H}, \mathrm{t}, J=8.7 \mathrm{~Hz})$, $3.43(1 \mathrm{H}, \mathrm{m}), 3.30(1 \mathrm{H}, \mathrm{m}), 2.55(1 \mathrm{H}, \mathrm{dd}, J=9.3$ and $13.5 \mathrm{~Hz})$, $2.39(1 \mathrm{H}+2 \times 1 \mathrm{H}, \mathrm{m}) .{ }^{13} \mathrm{C}$ NMR $\left(100 \mathrm{MHz}, \mathrm{D}_{2} \mathrm{O}\right) \delta 182.1,181.5$,
$176.9,176.7,104.5,104.1,71.3,71.2,46.3,45.3,40.5,40.1$. HRMS (ES-) $m / z 175.0236\left([\mathrm{M}-2 \mathrm{Li}+\mathrm{H}]^{-}, \mathrm{C}_{6} \mathrm{H}_{7} \mathrm{O}_{6}\right.$ requires 175.0243$)$.

Dilithium 2-(Benzyloxymethyl)-4-oxoglutarate 1b. ${ }^{1} \mathrm{H}$ NMR $\left(400 \mathrm{MHz}, \mathrm{D}_{2} \mathrm{O}\right) \delta 7.38(5 \mathrm{H}, \mathrm{m}), 4.52(2 \mathrm{H}, \mathrm{s}), 3.68(1 \mathrm{H}, \mathrm{dd}, J=$ 6.0 and $9.7 \mathrm{~Hz}), 3.59(1 \mathrm{H}$, dd, $J=6.7$ and $9.7 \mathrm{~Hz}), 3.05(1 \mathrm{H}$, dd, $J=7.2$ and $17.1 \mathrm{~Hz}), 2.96(1 \mathrm{H}, \mathrm{m}), 2.84(1 \mathrm{H}, \mathrm{dd}, J=4.8$ and $17.2 \mathrm{~Hz}) .{ }^{13} \mathrm{C}$ NMR $\left(100 \mathrm{MHz}, \mathrm{D}_{2} \mathrm{O}\right) \delta 204.1,180.6,169.4,137.4$, $128.7,128.4,128.1,72.6,71.1,43.6,39.3$. HRMS (ES-) $\mathrm{m} / \mathrm{z}$ $271.0795\left(\left[\mathrm{M}-\mathrm{Li}^{-}, \mathrm{C}_{13} \mathrm{H}_{12} \mathrm{LiO}_{6}\right.\right.$ requires 271.0794$)$.

Trilithium 4-Oxobutane-1,2,4-tricarboxylate 1c. ${ }^{1} \mathrm{H}$ NMR (400 $\left.\mathrm{MHz}, \mathrm{D}_{2} \mathrm{O}\right) \delta 3.00(1 \mathrm{H}$, dd, $J=5.9$ and $16.4 \mathrm{~Hz}), 2.94(1 \mathrm{H}, \mathrm{m})$, $2.84(1 \mathrm{H}$, dd, $J=5.0$ and $16.4 \mathrm{~Hz}), 2.56(1 \mathrm{H}$, dd, $J=5.5$ and $15.3 \mathrm{~Hz}), 2.28(1 \mathrm{H}, \mathrm{dd}, J=8.6$ and $15.3 \mathrm{~Hz}) .{ }^{13} \mathrm{C}$ NMR $(100$ $\left.\mathrm{MHz}, \mathrm{D}_{2} \mathrm{O}\right) \delta 202.6,181.6,179.6,168.4,41.1,40.6,40.1$. HRMS (ES-) $\mathrm{m} / \mathrm{z} 203.0196\left([\mathrm{M}-2 \mathrm{Li}+\mathrm{H}]^{-}, \mathrm{C}_{7} \mathrm{H}_{7} \mathrm{O}_{7}\right.$ requires 203.0192$)$.

General Procedure for the Synthesis of Lithium Oxoglutarates 1d and 1e. To a solution of $6 \mathbf{d}$ or $6 \mathrm{e}(2 \mathrm{mmol})$ in $\mathrm{MeOH}$ $(20 \mathrm{~mL})$ was added $10 \% \mathrm{Pd} / \mathrm{C}(50 \mathrm{mg})$. The solution was degassed under reduced pressure and then flushed with hydrogen using a balloon. The suspension was stirred at room temperature for 30 min before filtration on a $0.2 \mu \mathrm{m}$ membrane and concentration under reduced pressure. The residue was dissolved in $\mathrm{H}_{2} \mathrm{O}(10 \mathrm{~mL})$ and the solution brought to $\mathrm{pH} 7.6$ by addition of an aqueous $0.4 \mathrm{M}$ solution of $\mathrm{LiOH}$. Water was evaporated under reduced pressure to give 1d or $1 \mathbf{e}$ isolated in quantitative yields as white solids.

Dilithium 2-(2-Methoxy-2-oxoethyl)-4-oxoglutarate 1d. ${ }^{1} \mathrm{H}$ NMR $\left(400 \mathrm{MHz}, \mathrm{D}_{2} \mathrm{O}\right) \delta 3.66(3 \mathrm{H}, \mathrm{s}), 3.10(1 \mathrm{H}, \mathrm{dd}, J=7.1$ and $18.0 \mathrm{~Hz}), 3.05(1 \mathrm{H}, \mathrm{m}), 2.92(1 \mathrm{H}, \mathrm{dd}, J=7.2$ and $17.6 \mathrm{~Hz}), 2.61$ $(1 \mathrm{H}, \mathrm{dd}, J=7.8$ and $16.4 \mathrm{~Hz}), 2.52(1 \mathrm{H}, \mathrm{dd}, J=6.2$ and 16.3 $\mathrm{Hz}) .{ }^{13} \mathrm{C}$ NMR $\left(100 \mathrm{MHz}, \mathrm{D}_{2} \mathrm{O}\right) \delta 203.8,181.4,175.4,169.4,52.2$, 41.4, 39.3, 36.3. HRMS (ES-) $\mathrm{m} / \mathrm{z} 217.0351\left(\left[\mathrm{M}-2 \mathrm{Li}+\mathrm{H}^{-}\right.\right.$, $\mathrm{C}_{8} \mathrm{H}_{9} \mathrm{O}_{7}$ requires 217.0348).

Dilithium 2-(3-Methoxy-3-oxopropyl)-4-oxoglutarate 1e. ${ }^{1} \mathrm{H}$ NMR $\left(400 \mathrm{MHz}, \mathrm{D}_{2} \mathrm{O}\right) \delta 3.69(3 \mathrm{H}, \mathrm{s}), 3.04(1 \mathrm{H}, \mathrm{dd}, J=7.8$ and $17.5 \mathrm{~Hz}), 2.86(1 \mathrm{H}, \mathrm{dd}, J=6.1$ and $17.6 \mathrm{~Hz}), 2.65(1 \mathrm{H}, \mathrm{m}), 2.42$ $(2 \mathrm{H}, \mathrm{t}, J=7.8 \mathrm{~Hz}), 1.79(2 \mathrm{H}, \mathrm{m}) .{ }^{13} \mathrm{C}$ NMR $\left(100 \mathrm{MHz}, \mathrm{D}_{2} \mathrm{O}\right) \delta$ $204.8,182.1,177.1,170.2,52.8,42.4,42.1,32.1,27.0$. HRMS (ES-) $m / 2231.0514\left([\mathrm{M}-2 \mathrm{Li}+\mathrm{H}]^{-}, \mathrm{C}_{9} \mathrm{H}_{11} \mathrm{O}_{7}\right.$ requires 231.0505)

(2S,4S)-4-(Benzyloxymethyl)glutamic Acid $2 \mathrm{~b}$. To a solution of racemic $1 \mathrm{~b}(154 \mathrm{mg}, 0.55 \mathrm{mmol})$ in water $(25 \mathrm{~mL})$ was added cysteine sulfinic acid $(84 \mathrm{mg}, 0.55 \mathrm{mmol})$. The $\mathrm{pH}$ of the solution was adjusted to 7.6 with $1 \mathrm{M} \mathrm{NaOH}$ before the addition of $E$. coli AAT (0.4 mg, 20 Units). The reaction was stirred slowly at room temperature and monitored by titration of pyruvate: $5 \mu \mathrm{L}$ aliquots of the reaction mixture were added to $995 \mu \mathrm{L}$ of $0.1 \mathrm{M}$ potassium phosphate buffer, $\mathrm{pH} 7.6$, containing $\mathrm{NADH}(0.2 \mathrm{mM})$ and lactate dehydrogenase (1 Unit). Pyruvate concentration was calculated from the $\Delta O D$ measured at $340 \mathrm{~nm}$ using $\epsilon_{\mathrm{NADH}}=6220 \mathrm{M}^{-1} \cdot \mathrm{cm}^{-1}$. When a conversion rate of $40 \%$ was reached, the reaction mixture was rapidly passed through a column of dowex $50 \mathrm{WX} 8$ resin $\left(\mathrm{H}^{+}\right.$ form, $25 \mathrm{~mL})$. The column was then washed with water $(100 \mathrm{~mL})$ until complete elution of CSA and then eluted with $1 \mathrm{M} \mathrm{NH}_{4} \mathrm{OH}$. The ninhydrin positive fractions were combined and concentrated to dryness under reduced pressure. The residue was diluted in water $(5 \mathrm{~mL})$ and, if necessary, the $\mathrm{pH}$ adjusted to 7.0 with $1 \mathrm{M} \mathrm{NaOH}$ before adsorption of the product on a column of dowex $1 \times 8$ resin (200-400 Mesh, $\mathrm{AcO}^{-}$form, $1.5 \mathrm{~cm} \times 12 \mathrm{~cm}$ ). The column was washed with water $(50 \mathrm{~mL})$ and then eluted with an $\mathrm{AcOH}$ gradient $(0.1-1 \mathrm{M})$. The ninhydrin positive fractions were combined and concentrated under reduced pressure. The residue was dissolved in water $(4 \mathrm{~mL})$ and the solution was lyophilized to afford $\mathbf{2 b}$ (64 $\mathrm{mg}, 43 \%)$ as a white solid; $\mathrm{mp} 144{ }^{\circ} \mathrm{C} ;[\alpha]^{25} \mathrm{D}=+31.0($ c $1.0,6$ $\mathrm{N} \mathrm{HCl}) .{ }^{1} \mathrm{H}$ NMR $\left(400 \mathrm{MHz}, \mathrm{D}_{2} \mathrm{O}\right) \delta 7.41(5 \mathrm{H}, \mathrm{m}), 4.58(2 \mathrm{H}, \mathrm{s})$, $3.98(1 \mathrm{H}, \mathrm{t}, J=6.8 \mathrm{~Hz}), 3.81(1 \mathrm{H}$, dd, $J=5.1$ and $10.0 \mathrm{~Hz}), 3.76$ $(1 \mathrm{H}, \mathrm{dd}, J=5.8$ and $10.0 \mathrm{~Hz}), 2.97(1 \mathrm{H}, \mathrm{m}), 2.38(1 \mathrm{H}, \mathrm{m}), 2.04$ $(1 \mathrm{H}, \mathrm{m}) .{ }^{13} \mathrm{C}$ NMR $\left(100 \mathrm{MHz}, \mathrm{D}_{2} \mathrm{O}\right) \delta 180.1,174.2,137.4,128.7$, $128.4,128.2,72.8,71.4,53.2,44.8,30.0$. HRMS (ES-) $\mathrm{m} / \mathrm{z}$ 266.1033 ([M $-\mathrm{H}]^{-}, \mathrm{C}_{13} \mathrm{H}_{16} \mathrm{NO}_{5}$ requires 266.1028). Anal. $\left(\mathrm{C}_{13} \mathrm{H}_{17} \mathrm{NO}_{5} \cdot 0.1 \mathrm{H}_{2} \mathrm{O}\right) \mathrm{C}, \mathrm{H}, \mathrm{N}$. 
(25,4R)-4-(3-Methoxy-3-oxopropyl)glutamic Acid 2e. It was prepared following the procedure already described for $\mathbf{2 b}$, except for the first chromatography step on dowex $50 \mathrm{WX} 8$ that was omitted. 2e was isolated as a white solid ( $45 \mathrm{mg}, 39 \%) ; \mathrm{mp} 135$ ${ }^{\circ} \mathrm{C} ;[\alpha]^{25} \mathrm{D}=+29.5(c 1.0,6 \mathrm{~N} \mathrm{HCl}) .{ }^{1} \mathrm{H}$ NMR $\left(400 \mathrm{MHz}, \mathrm{D}_{2} \mathrm{O}\right)$ $\delta 3.75(1 \mathrm{H}, \mathrm{dd}, J=5.4$ and $8.6 \mathrm{~Hz}), 3.70(3 \mathrm{H}, \mathrm{s}), 2.58(1 \mathrm{H}, \mathrm{m})$, $2.47(2 \mathrm{H}, \mathrm{m}), 2.25(1 \mathrm{H}$, ddd, $J=5.2,9.6$ and $14.8 \mathrm{~Hz}), 1.92(3 \mathrm{H}$, m). ${ }^{13} \mathrm{C}$ NMR $\left(100 \mathrm{MHz}, \mathrm{D}_{2} \mathrm{O}\right) \delta 179.2,176.2,173.8,53.1,52.2$, $41.8,32.5,31.2,27.0$. HRMS (ES+) $\mathrm{m} / \mathrm{z} 234.0982\left([\mathrm{M}+\mathrm{H}]^{+}\right.$, $\mathrm{C}_{9} \mathrm{H}_{16} \mathrm{NO}_{6}$ requires 234.0978). Anal. $\left(\mathrm{C}_{9} \mathrm{H}_{15} \mathrm{NO}_{6} \cdot 0.66 \mathrm{H}_{2} \mathrm{O}\right) \mathrm{C}$, $\mathrm{H}, \mathrm{N}$.

(2S,4S)-4-(Hydroxymethyl)glutamic Acid 2a. To a solution of 2b $(48 \mathrm{mg}, 0.18 \mathrm{mmol})$ in $\mathrm{H}_{2} \mathrm{O}(5 \mathrm{~mL})$ was added $10 \% \mathrm{Pd} / \mathrm{C}(10$ $\mathrm{mg}$ ). The solution was degassed under reduced pressure and then flushed with hydrogen using a balloon. The suspension was stirred at room temperature for $4 \mathrm{~h}$ before filtration on a $0.2 \mu \mathrm{m}$ membrane and concentration under reduced pressure. 2a was purified by chromatography on dowex $1 \times 8$ as described for $\mathbf{2 b}$ and isolated as a white solid $(31 \mathrm{mg}, 97 \%)$; $\mathrm{mp} 145^{\circ} \mathrm{C} ;[\alpha]^{25} \mathrm{D}=+26.0(\mathrm{c} 1.1$, $6 \mathrm{~N} \mathrm{HCl}) .{ }^{1} \mathrm{H}$ NMR $\left(400 \mathrm{MHz}, \mathrm{D}_{2} \mathrm{O}\right) \delta 3.81(3 \mathrm{H}, \mathrm{m}), 2.76(1 \mathrm{H}$, m) $2.30(1 \mathrm{H}$, ddd, $J=5.4,9.4$ and $14.8 \mathrm{~Hz}), 1.99(1 \mathrm{H}$, ddd, $J=$ 4.6, 8.0 and $14.8 \mathrm{~Hz}) .{ }^{13} \mathrm{C}$ NMR $\left(100 \mathrm{MHz}, \mathrm{D}_{2} \mathrm{O}\right) \delta 180.6,174.4$, 63.3, 53.3, 47.0. 29.8. HRMS (ES+) $m / z 178.0719\left([\mathrm{M}+\mathrm{H}]^{+}\right.$, $\mathrm{C}_{6} \mathrm{H}_{12} \mathrm{NO}_{5}$ requires 178.0715). Anal. $\left(\mathrm{C}_{6} \mathrm{H}_{11} \mathrm{NO}_{5} \cdot 0.33 \mathrm{H}_{2} \mathrm{O}\right) \mathrm{C}$, $\mathrm{H}, \mathrm{N}$.

(2S,4S)-4-(2-Hydroxy-2-oxoethyl)glutamic Acid 2c. The ketoacid 1c (170 mg, $0.74 \mathrm{mmol})$ was used in a transamination reaction as described for $\mathbf{2 b}$. When a conversion rate close to $40 \%$ was reached, an aqueous $6 \mathrm{~N} \mathrm{HCl}$ solution $(25 \mathrm{~mL})$ was added to the reaction mixture, which was then heated at $100^{\circ} \mathrm{C}$ for $4 \mathrm{~h}$ before concentration under reduced pressure. The residue was dissolved in water $(10 \mathrm{~mL})$ and the $\mathrm{pH}$ adjusted to 7 before the two-step purification done as described for $\mathbf{2 b}$. $2 \mathbf{c}$ was thus isolated as a white solid $(63 \mathrm{mg}, 41 \%) ; \mathrm{mp} 145^{\circ} \mathrm{C}:[\alpha]^{25} \mathrm{D}=+8.0(c 1.0,6 \mathrm{~N}$ $\mathrm{HCl}) .{ }^{1} \mathrm{H}$ NMR $\left(400 \mathrm{MHz}, \mathrm{D}_{2} \mathrm{O}\right) \delta 3.88(1 \mathrm{H}$, dd, $J=5.4$ and 8.1 $\mathrm{Hz}), 2.68(1 \mathrm{H}, \mathrm{m}), 2.98(1 \mathrm{H}, \mathrm{m}), 2.74(2 \mathrm{H}, \mathrm{m}), 2.34(1 \mathrm{H}, \mathrm{ddd}, J=$ $5.7,10.0,15.0 \mathrm{~Hz}) .{ }^{13} \mathrm{C}$ NMR $\left(100 \mathrm{MHz}, \mathrm{D}_{2} \mathrm{O}\right) \delta 177.1,175.4$, $171.3,51.2,37.5,35.6,31.1$. HRMS (ES+) $\mathrm{m} / \mathrm{z} 206.0672$ ([M + $\mathrm{H}]^{+}, \mathrm{C}_{7} \mathrm{H}_{12} \mathrm{NO}_{6}$ requires 206.0665). Anal. $\left(\mathrm{C}_{7} \mathrm{H}_{11} \mathrm{NO}_{6} \cdot 1.5 \mathrm{H}_{2} \mathrm{O}\right) \mathrm{C}$, $\mathrm{H}, \mathrm{N}$.

(2S,4R)-4-(3-Hydroxy-3-oxopropyl)glutamic Acid 2f. It was prepared from $1 \mathrm{e}(250 \mathrm{mg}, 1.0 \mathrm{mmol})$ following the procedure described for $\mathbf{2 c}$. $2 \mathrm{f}$ was isolated as a white solid $(90 \mathrm{mg}, 41 \%)$; mp $95^{\circ} \mathrm{C} ;[\alpha]^{25}=+6.4(c 1.1,6 \mathrm{~N} \mathrm{HCl}) .{ }^{1} \mathrm{H}$ NMR $(400 \mathrm{MHz}$, $\left.\mathrm{D}_{2} \mathrm{O}\right) \delta 3.77(1 \mathrm{H}$, dd, $J=5.6$ and $8.2 \mathrm{~Hz}), 2.61(1 \mathrm{H}, \mathrm{m}), 2.41(2 \mathrm{H}$, $\mathrm{m}), 2.25(1 \mathrm{H}$, ddd, $J=5.6,9.7$ and $15.0 \mathrm{~Hz}), 1.89(3 \mathrm{H}, \mathrm{m}) .{ }^{13} \mathrm{C}$ NMR $\left(100 \mathrm{MHz}, \mathrm{D}_{2} \mathrm{O}\right) \delta 178.5,177.6,173.4,52.8,41.2,32.2$, $31.2,26.9$. HRMS (ES+) $m / z 220.0815\left([\mathrm{M}+\mathrm{H}]^{+}, \mathrm{C}_{8} \mathrm{H}_{15} \mathrm{NO}_{6}\right.$ requires 220.0821). Anal. $\left(\mathrm{C}_{8} \mathrm{H}_{14} \mathrm{NO}_{6} \cdot 1.2 \mathrm{H}_{2} \mathrm{O}\right) \mathrm{C}, \mathrm{H}, \mathrm{N}$.

6-Oxopiperidine-2,4-dicarboxylic Acid 7. The ketoacid 1d ( 250 $\mathrm{mg}, 1.08 \mathrm{mmol}$ ) was used in a transamination reaction as described for $\mathbf{2 b}$. After elution of the dowex $50 \mathrm{WX} 8$ resin with aqueous $1 \mathrm{M}$ ammonia, the fractions containing 7 were concentrated under reduced pressure. The lactame 7 was isolated as a white solid (70 mg, $35 \%)$. mp $225{ }^{\circ} \mathrm{C} ;[\alpha]^{25} \mathrm{D}=-25.4\left(c 0.8, \mathrm{H}_{2} \mathrm{O}\right) .{ }^{1} \mathrm{H}$ NMR $\left(400 \mathrm{MHz}, \mathrm{D}_{2} \mathrm{O}\right) \delta 4.20(1 \mathrm{H}$, dd, $J=5.4$ and $10.2 \mathrm{~Hz}), 3.03(1 \mathrm{H}$, tdd, $J=3.6,6.0,9.6 \mathrm{~Hz}), 2.67-2.50(3 \mathrm{H}, \mathrm{m}), 2.74(2 \mathrm{H}, \mathrm{m}), 1.92$ $(1 \mathrm{H}, \mathrm{td}, J=10.0$ and $13.6 \mathrm{~Hz}) \cdot{ }^{13} \mathrm{C}$ NMR $\left(100 \mathrm{MHz}, \mathrm{D}_{2} \mathrm{O}\right) \delta$ $177.2,175.8,173.5,54.4,36.9,32.0,27.3$. HRMS (ES+) $\mathrm{m} / \mathrm{z}$ $253.0674\left([\mathrm{M}+\mathrm{Na}]^{+}, \mathrm{C}_{10} \mathrm{H}_{14} \mathrm{NaO}_{6}\right.$ requires 253.0688$)$.

AMPA, KA, and NMDA Binding Assays. Glu analogues $2 \mathbf{a}-\mathbf{j}$ were evaluated for AMPA, KA, NMDA (CGP 39653) binding affinity in native rat synaptosomes, in accordance with previously described experimental procedures. ${ }^{12}$

iGluR5-7 Binding Assay. Rat iGluR5 $(Q)_{1 \mathrm{~b}}$, iGluR6(V,C,R)a, and iGluR7a were inserted into recombinant baculoviruses, receptors expressed by infection of $S f 9$ insect cells and infected $S f 9$ cell membranes utilized for radioligand binding assays. Cells were maintained in BaculoGold Max-XP serum-free medium (BD Biosciences-Pharmingen. San Diego, CA) according to standard protocols in "Guide to Baculovirus Expression Vector
Systems and Insect Cell Culture Techniques" (Life Technologies, Paisley, UK) and "Baculovirus Expression Vector System: Procedures and Methods Manual", 2nd ed., (Pharmingen). $\left[{ }^{3} \mathrm{H}\right]-$

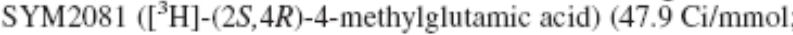
ARC Inc., St. Louis, MO) microtiter plate binding assays were performed in $250 \mu \mathrm{L}$ assay buffer $(50 \mathrm{mM}$ Tris- $\mathrm{HCl}, \mathrm{pH} 7.1$ at $4{ }^{\circ} \mathrm{C}$ ) at a protein concentration from $10-50 \mu \mathrm{g} / \mathrm{mL}$, incubating for $1-2 \mathrm{~h}$ at $4{ }^{\circ} \mathrm{C}$. Bound and free radiolabels were separated by cold filtration through GF/B glass fiber filters (UniFilter-96, Perkin-Elmer, Waltham MA) on a Perkin-Elmer FilterMate manifold using two washes with cold assay buffer. Nonspecific binding was determined in the presence of $1 \mathrm{mM} \mathrm{L}$-Glu. Competition studies were performed using $1-5 \mathrm{nM}$ radiolabel in the presence of $10 \mathrm{nM}$ to $1 \mathrm{mM}$ cold ligand. Filters were dried $1 \mathrm{~h}$ at $50^{\circ} \mathrm{C}$ and then $50 \mu \mathrm{L} /$ well Microscint 20 was added. Radioactivity was detected as DPM using a TopCounter. The affinity of the radiolabel for the kainate receptors was determined from saturation binding experiments, $K_{d}$ (mean \pm SEM): iGluR5 $(Q)_{1 \mathrm{~b}}, 0.663 \pm 0.035 \mathrm{nM}$; iGluR6 $(V, C, R)$ a, $17.0 \pm 3.0$ $\mathrm{nM}$; iGluR7a, $5.69 \pm 1.12 \mathrm{nM}$. Competition data were analyzed using Grafit v3.00 (Erithacus Software Ltd., Horley, UK) and fit to equations as previously described for the determination of $K_{\mathrm{i} \cdot}{ }^{21}$

mGluR Assays. Mammalian Cell Tissue Culture and Transfection. CHO cells were grown in T150 flasks in Dulbecco's modified Eagle medium (DMEM) (Invitrogen, Carlsbad, CA) with supplements ( $10 \%$ bovine calf serum, $4 \mathrm{mM}$ glutamine, 100 units $\mathrm{mL}$ penicillin $100 \mu \mathrm{g} / \mathrm{mL}$ streptomycin) at $37^{\circ} \mathrm{C}, 5 \% \mathrm{CO}_{2}$. Stock plates of $\mathrm{CHO}$ cells were trypsinized and split 1:6 every $3-4$ days. COS-7 cells were grown in $225 \mathrm{~cm} 2$ flasks in Dulbecco's modified Eagle medium (DMEM) with supplements ( $10 \%$ bovine calf serum, $4 \mathrm{mM}$ glutamine, 100 units $/ \mathrm{mL}$ penicillin $100 \mu \mathrm{g} / \mathrm{mL}$ streptomycin) at $37^{\circ} \mathrm{C}, 5 \% \mathrm{CO}_{2}$. Stock plates of COS-7 cells were trypsinized and split $1: 6$ every $3-4$ days.

The rat metabotropic glutamate receptors 2 and 3 were cloned as follows; the coding regions of mGluR2 and mGluR3 were amplified by PCR from rat brain cDNA in 3 fragments that were ligated using internal restriction sites. A Kozak consensus sequence was included in the first PCR primer. The full-length receptor cDNAs were subcloned into mammalian expression vectors suitable for stable and transient expression. The chimera, $\mathrm{C}$ elegans $\mathrm{G}_{\alpha} \mathrm{Qi3}$, cDNA was cloned by a PCR approach and sequenced by Lundbeck Research. USA, as previously described. ${ }^{22,23}$ Both cDNAs were transiently transfected into $\mathrm{CHO}$ cells in T150 flasks by the Lipofectamine Plus (Invitrogen Carlsbad, California) method using a total of $10 \mu \mathrm{g}$ of DNA/ $\sim 7 \times 10^{6}$ cells. The standard cDNA transfection ratio was $8: 2(8 \mu \mathrm{g}$ GPCR cDNA and $2 \mu \mathrm{g}$ chimera $\mathrm{G} \alpha$ cDNA). The cDNAs for rat metabotropic glutamate receptors 1 and 5 were generous gifts from Prof. S. Nakanishi (Kyoto University, Kyoto, Japan). These cDNAs were transiently transfected into HEK293 cells using the same method.

Membrane Preparation and $\left[{ }^{3} 2 \mathrm{H}\right] \mathrm{LY} 43915$ Binding. CHO cells were transiently transfected as described above. They were harvested $48 \mathrm{~h}$ after transfection and washed 3 times with cold PBS. The cells were centrifuged at 1200 RPM, $4{ }^{\circ} \mathrm{C}$, for 10 $\mathrm{min}$, and the pellet was resuspended in wash buffer A $(20 \mathrm{mM}$ HEPES, $10 \mathrm{mM}$ EDTA, $\mathrm{pH} 7.4$ ). The pellet was sonicated on the Virsonic 300 model, 4 times in $30 \mathrm{~s}$ intervals on ice, centrifuged for $10 \mathrm{~min}$ at $1200 \mathrm{RPM}, 4^{\circ} \mathrm{C}$. The supernatant was collected and centrifuged for $20 \mathrm{~min}$ at $17000 \mathrm{RPM}$. The pellet was resuspended in wash buffer $B(20 \mathrm{mM}$ HEPES, $0.1 \mathrm{mM}$ EDTA, $\mathrm{pH}$ 7.4) and homogenized for $10 \mathrm{~s}$. Protein concentration was determined by Bradford method. ${ }^{24}$ The membrane was stored at $-80{ }^{\circ} \mathrm{C}$ prior to use.

Binding assays were performed as described with slight modifications. ${ }^{25}$ Briefly, after thawing, the membrane homogenates resuspended in $50 \mathrm{mM}$ Tris- $\mathrm{HCl}, 2 \mathrm{mM} \mathrm{MgCl}_{2}$, and $2 \mathrm{mM}$ $\mathrm{CaKCl}_{2}$ binding buffer at $\mathrm{pH} 7.0$ to a final assay concentration of $10 \mu \mathrm{g}$ protein/well for $\left[{ }^{3} \mathrm{H}\right] \mathrm{LY} 341495$ scintillation proximity assay (SPA) binding. Incubations included $2 \mathrm{nM}\left[{ }^{3} \mathrm{H}\right] \mathrm{LY} 341495$, $1.0 \mathrm{mg}$ of WGA-SPA beads (GE Health, Buckinghamshire,UK). 
Each well contained either buffer or varying concentrations of compound. Nonspecific binding was defined with $10 \mu \mathrm{M}$ LY341495. After $45 \mathrm{~min}$ incubation on ice, the 96-well SPA microplate was further incubated at $4{ }^{\circ} \mathrm{C}$ overnight and counted with Wallac MicroBeta TriLux. At the $K_{d}$ value, the nonspecific binding for $\left[{ }^{3} \mathrm{H}\right] \mathrm{LY} 341495$ was approximately $5 \%$. IC $C_{50}$ values were derived from the inhibition curve and $K_{\mathrm{i}}$ values were calculated according to Cheng and Prusoff equation $K_{\mathrm{i}}=\mathrm{IC}_{50} /$ $\left(1+[\mathrm{L}] / K_{d}\right)$ (Cheng and Prusoff 1973), where [L] is the concentration of radioligand and $K_{\mathrm{d}}$ is its dissociation constant at the receptor, derived from the saturation isotherm.

Calcium Mobilization Assay. Twenty-four hours after transient transfection, cells were seeded into 384-well black wall microtiter plates coated with poly-D-lysine for assay the following day. Just prior to assay, media was aspirated and cells were dyeloaded ( $25 \mu \mathrm{L} /$ well) with $3 \mu \mathrm{M}$ Fluo- $4 / 0.01 \%$ pluronic acid in assay buffer (HBSS $=$ Hank's buffered saline-check: $150 \mathrm{mM}$ $\mathrm{NaCl}, 5 \mathrm{mM} \mathrm{KCl}, 1 \mathrm{mM} \mathrm{CaCl}, 1 \mathrm{mM} \mathrm{MgCl}$, plus $20 \mathrm{mM}$ HEPES, $\mathrm{pH} 7.4,0.1 \%$ BSA and $2.5 \mathrm{mM}$ probenicid) for $1 \mathrm{~h}$ in $5 \% \mathrm{CO}_{2}$ at $37{ }^{\circ} \mathrm{C}$. After excess dye was discarded, cells were washed in assay buffer and layered with a final volume equal to $30 \mu \mathrm{L} /$ well. Basal fluorescence was monitored in a fluorometric imaging plate reader (FLIPR, Molecular Devices) with an excitation wavelength of $488 \mathrm{~nm}$ and an emission range of 500 to $560 \mathrm{~nm}$. Laser excitation energy was adjusted so that basal fluorescence readings were approximately 10000 relative fluorescent units. Cells were stimulated with an $\mathrm{EC}_{20}$ or $\mathrm{EC}_{10}$ concentration of glutamate in the presence of a test compound, both diluted in assay buffer, and relative fluorescent units were measured at defined intervals (exposure $=0.6 \mathrm{~s}$ ) over a $3 \mathrm{~min}$ period at room temperature. Basal readings derived from negative controls were subtracted from all samples. Maximum change in fluorescence was calculated for each well. Concentrationresponse curves derived from the maximum change in fluorescence were analyzed by nonlinear regression (Hill equation).

In Silico Studies. The modeling software MOE (version 2006.08, Chemical Computing Group) was used with the built-in mmff $94 \mathrm{x}$ force field and $\mathrm{GB} / \mathrm{SA}$ solvation model. iGluR X-ray crystal structures (Brookhaven Protein Data Bank (PDB) data files) were submitted to the following preparative procedure: addition of hydrogen atoms, fixing heavy atoms, energy minimization, unfixing heavy atoms. Docking studies were carried out with parameter setup: explicit water molecules were excluded, ligand conformational database (LCD); placement methodology: alpha triangle with PH4-pharmacophore filtering ( $\alpha$ ammonium group, $1.6 \mathrm{vol}$ ) and pocket atom as restrains; London-dG scoring-function (readout: free energy of binding in $\mathrm{kcal} / \mathrm{mol}$ ). LCDs were generated by introducing two dihedral angle restrains to the Glu analogue to impose a folded conformation Glu scaffold, then subsequently performing a stochastic conformational search with standard parameter setup. (Dihedrals: ${ }^{+} \mathrm{NH} 3 \mathrm{CH}-\mathrm{CH} 2 \mathrm{CHR}:-79.2 \pm 5^{\circ}$, weight 100.000 ; $\mathrm{CHCH}_{2}-\mathrm{CHRCOO}^{-}:-66.6 \pm 5^{\circ}$, weight 100.000 . Dihedral angle values adapted from Glu when crystallized with iGluR6, PDB code 1s50). Homology models: receptor protein sequences KA1(Q01812: 956aa), KA2(NP_113696; 979aa), iGluR5(P22756; 949aa), iGluR6(P42260; 908aa), iGluR7(P42264: 919aa) were obtained from the Brookhaven Protein Data Bank and homology models built onto iGluR5 (PDB code: 1txf) using the built-in alignment algorithm (standard parameter setup).

Acknowledgment. We thank The Carlsberg Foundation, the Lundbeck Foundation, The Danish Medical Research Council, the French National Center for Scientific Research (CNRS), and the Novo Nordisk Foundation for funding. We are grateful to Pr. Kagamiyama's group (Osaka Medical College) for providing us with the AAT overexpressing E. coli strain. Dr. Susan Amara is thanked for providing us with the EAAT cDNAs.

Supporting Information Available: Combustion analysis data for $2 \mathrm{a}-\mathbf{f}$ and $6 \mathrm{a}-\mathbf{e},{ }^{1} \mathrm{H}$ and ${ }^{13} \mathrm{C}$ NMR spectra of compounds $2 \mathrm{a}-\mathbf{f}$.
Figures $2-4$ as PDB and MOE file formats. This material is available free of charge via the Internet at http://pubs.acs.org.

\section{References}

(1) Meldrum, B. S. Glutamate as a neurotransmitter in the brain: Review of physiology and pathology. J. Nutr. 2000, 130, 1007S-1015S.

(2) Brāuner-Osborne, H.; Egebjerg, J.; Nielsen, E. O.; Madsen, U.; Krogsgaard-Larsen, P. Ligands for glutamate receptors: Design and therapeutic prospects. J. Med. Chem. 2000, 43, 2609-2645.

(3) Beart, P. M.; O'Shea, R. D. Transporters for L-glutamate: An update on their molecular pharmacology and pathological involvement. Br. J. Pharmacol. 2007, 150, 5-17.

(4) Wisden, W.; Seeburg, P. H. A Complex Mosaic of High-Affinity Kainate Receptors in Rat Brain J Neurosci 1993, J3, 3582-3598.

(5) Ferraguti, F.: Shigemoto, R. Metabotropic glutamate receptors. Cell Tissue Res. 2006, 326, 483-504.

(6) Alaux, S.; Kusk, M.; Sagot, E.; Bolte, J.; Jensen, A. A.; BraunerOsborne, H.; Gefflaut, T.; Bunch, L. Chemoenzymatic synthesis of a series of 4-substituted glutamate analogues and pharmacological characterization at human glutamate transporters subtypes $1-3$. J. Med. Chem. 2005, 48, 7980-7992.

(7) Sagot, E.; Jensen, A. A.; Pickering, D. S.; Pu, X.; Umberti, M.; Stensbøl, T. B.; Nielsen, B.; Assaf, Z.; Aboab, B.; Bolte, J.; Gefflaut, T.: Bunch, L. Chemo-Enzymatic Synthesis of (2S,4R)-2-Amino-4-(3(2,2-diphenylethylamino)-3-oxopropyl)pentanedioic Acid: A Novel Selective Inhibitor of Human Excitatory Amino Acid Transporter Subtype 2. J. Med. Chem. 2008, 51, 4085-4092.

(8) Xian, M.; Alaux, S.; Sagot, E.; Gefflaut, T. Chemoenzymatic Synthesis of Glutamic Acid Analogues: Substrate Specificity and Synthetic Applications of Branched Chain Aminotransferase from Escherichia coli. J. Org. Chem. 2007, 72, 7560-7566.

(9) Borrell, J. I.; Teixido, J.; Martinez-Teipel, B.; Matallana, J. L.; Copete, M. T.; Llimargas, A.; Garcia, E. Synthesis and Biological Activity of 4-Amino-7-oxo-Substituted Analogues of 5-Deaza-5,6,7,8-tetrahydrofolic Acid and 5,10-Dideaza-5,6,7,8-tetrahydrofolic Acid. J. Med. Chem. 1998, 41, 3539-3545.

(10) O'Leary, B. M.; Szabo, T.; Svenstrup, N.; Schalley, C. A.; Lutzen, A.; Schafer, M.; Rebek, J. "Flexiball" Toolkit: A Modular Approach to Self-Assembling Capsules. J. Am. Chem. Soc. 2001, I23, 1151911533.

(11) Johnson, W. S.; Werthema, L.; Bartlett, W. R.; Brocksom, T. J.; Li, T. T.; Faulkner, D. J.; Petersen, M. R. A Simple Stereoselective Version Of Claisen Rearrangement Leading To trans-Trisubstituted Olefinic Bonds. Synthesis Of Squalene. J. Am. Chem. Soc. 1970, 92, 741-743.

(12) Hermit, M. B.; Nielsen, B.; Greenwood, J. R.; Bunch, L.; Jorgensen, C. G.; Vestergaard, H. T.; Stensbol, T. B.; Sanchez, C.; KrogsgaardLarsen, P.; Madsen, U.; Bräuner-Osborne, H. Ibotenic acid and thioibotenic acid: a remarkable difference in activity at group III metabotropic glutamate receptors. Eur. J. Pharmacol. 2004, 486, 241250 .

(13) Naur, P.; Vestergaard, B.; Skov, L. K.; Egebjerg, J.; Gajhede, M.; Kastrup, J. S. Crystal structure of the kainate receptor GluR5 ligandbinding core in complex with (S)-glutamate. FEBS Lett. 2005, 579 , $1154-1160$.

(14) Mayer, M. L. Crystal structures of the GluR5 and GluR6 ligand binding cores: molecular mechanisms underlying kainate receptor selectivity. Neuron 2005, 45, 539-552.

(15) Nanao, M. H.; Green, T.; Stern-Bach, Y.; Heinemann, S. F.; Choe, S. Structure of the kainate receptor subunit GluR6 agonist-binding domain complexed with domoic acid. Proc. Natl. Acad. Sci. U.S.A. 2005, 102, complexed wit

(16) Bettler, B.; Egebjerg, J.; Sharma, G.; Pecht, G.; Hermansborgmeyer, I.; Moll, C.; Stevens, C. F.; Heinemann, S. Cloning of a putative glutamate receptor: a low affinity kainate-binding subunit. Neuron 1992, 8, 257-265

(17) Werner, P.; Voigt, M.; Keinanen, K.; Wisden, W.; Seeburg, P. H Cloning of A Putative High-Affinity Kainate Receptor Expressed Predominantly in Hippocampal CA3 Cells. Nature 1991, 351, 742744.

(18) Herb, A.; Burnashev, N.; Werner, P.; Sakmann, B.; Wisden, W.; Seeburg, P. H. The KA-2 subunit of excitatory amino acid receptors shows widespread expression in brain and forms ion channels with distantly related subunits. Neuron $1992,8,775-785$.

(19) Emiliozzi, R.; Pichat, L. A simple method for the preparation of cysteinesulfinic acid. Bull. Soc. Chim. Fr. 1959, 1887-1888.

(20) Kamitori, S.; Hirotsu, K.; Higuchi, T.; Kondo, K.; Inoue, K.; Kuramitsu, S.; Kagamiyama, H.; Higuchi, Y.; Yasuoka, N.; Kusunoki, M.; Matsuura, Y. Overproduction And Preliminary-X-Ray Characterization Of Aspartate Aminotransferase From Escherichia Coli. J. Biochem. 1987, 101, 813-816. 
(21) Nielsen, B. S.; Banke, T. G.; Schousboe, A.; Pickering, D. S . Pharmacological properties of homomeric and heteromeric GluR1(o) and GluR3(o) receptors. Eur. J. Pharmacol. 1998, 360 , $227-238$

(22) Walker, M. W.; Jones, K. A.; Tamm, J.; Zhong, H. L.; Smith, K. E.; Gerald, C.; Vaysse, P.; Branchek, T. A. Use of Caenorhabditis elegans $\mathrm{G}$ alpha(q) chimeras to detect G-protein-coupled receptor signals. J. Biomol. Screening 2005, 10, 127-136.

(23) Coward, P.; Chan, S. D. H.; Wada, H. G.; Humphries, G. M.; Conklin, B. R. Chimeric $\mathrm{G}$ proteins allow a high-throughput signaling assay of G(i)-coupled receptors. Anal. Biochem. 1999, 270, 242-248.
(24) Bradford, M. M. Rapid and sensitive method for quantitation of microgram quantities of protein utilizing principle of protein-dye binding. Anal. Biochem. 1976, 72, 248-254.

(25) Johnson, M. P.; Barda, D.; Britton, T. C.; Emkey, R.; Hornback, W. J.; Jagdmann, G. E.; McKinzie, D. L.; Nisenbaum, E. S.; Tizzano, J. P.; Schoepp, D. D. Metabotropic glutamate 2 receptor potentiators: receptor modulation, frequency-dependent synaptic activity, and efficacy in preclinical anxiety and psychosis model(s). Psychopharmacology 2005, 179, 271-283. 